Article

\title{
Evolution of Near-Shore Outwash Fans and Permafrost Spreading Under Their Surface: A Case Study from Svalbard
}

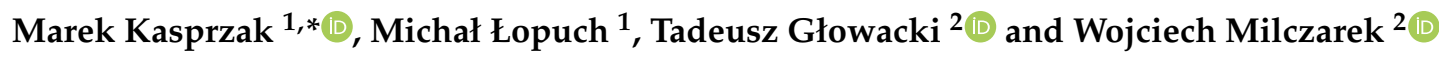 \\ 1 Instytut Geografii i Rozwoju Regionalnego, Uniwersytet Wrocławski, pl. Uniwersytecki 1, 50-137 Wrocław, \\ Poland; michal.lopuch@uwr.edu.pl \\ 2 Faculty of Geoengineering, Mining and Geology, Wrocław University of Science and Technology, Wybrzeże \\ Wyspiańskiego 27, 50-370 Wrocław, Poland; tadeusz.glowacki@pwr.edu.pl (T.G.); \\ wojciech.milczarek@pwr.edu.pl (W.M.) \\ * Correspondence: marek.kasprzak@uwr.edu.pl
}

Received: 25 December 2019; Accepted: 29 January 2020; Published: 3 February 2020

\begin{abstract}
The article presents geomorphological analysis results for two outwash fans (sandurs), Elveflya and Nottingham, in the marginal zone of the Werenskiold Glacier in the south-west part of the Spitsbergen. The main goal of this study was to reconstruct the morphological evolution of these landforms and to identify the permafrost zone under their surface. For this purpose, age data of fossils were compiled and compared with newly exposed and dated fossil tundra in the layer glaciotectonically deformed by the forming glacier end moraine. Using this method, a time frame was identified for the glacier advance and for the simultaneous formation of the outwash plains. It was concluded that the Elveflya surface has been built-up with deposits since the Little Ice Age. Sediment deposition ended in the late 1960s, due to hydrographic changes and the redirection of all proglacial waters towards the Nottingham bay. A photointerpretation analysis based on two orthophotomaps and LANDSAT scenes allowed the identification of five microfans in Elveflya, of which two youngest fans have a twice shorter range than the other three. The sixth microfan is currently shaped by deposits washed from the slope of the end moraine. An additional focus was placed on a currently active sandur, which fills the Nottingham bay, in order to identify its growth rate. The average growth rate of this surface increased from $5700 \mathrm{~m}^{2} \cdot$ year $^{-1}$ over the period of 1985-2000 to $24,900 \mathrm{~m}^{2} \cdot$ year $^{-1}$ over the period of 2010-2017. Electromagnetic measurements carried out on the surfaces of the sandurs demonstrated that the electrical resistivity of the ground is high in the apex of the Elveflya fan $(\rho \geq 1 \mathrm{k} \Omega$.m) and low in its toe (typically $\rho<200 \Omega$.m), as in the case of the Nottingham fan ground. In the interpretation advanced here, permafrost developed in the proximal part of the Elveflya sandur, which continues to be supplied by fresh groundwaters flowing from the glacier direction. Low electrical resistivity of the ground in the distal part of the outwash fan suggests the absence of ground ice in this zone, which is subjected to the intrusion of salty and comparatively warm seawater, reaching approximately $1 \mathrm{~km}$ inland under the surface of the low-elevated marine terrace. The identified zones additionally display different tendencies for vertical movements of the terrain surface, as identified with the Small Baseline Subset (SBAS) method. The proximal part of the Elveflya outwash fan is relatively stable, while its distal part lowers in the summer period by a maximum of $5 \mathrm{~cm}$. The resulting morphological changes include linear cracks having lengths up to $580 \mathrm{~m}$ and an arc line consistent with the coastline.
\end{abstract}

Keywords: permafrost; outwash-fan evolution; photogrammetry; electromagnetic induction; SBAS; Sentinel-1A/1B 


\section{Introduction}

Despite the fact that the Svalbard permafrost has been researched for many years and is well-documented in borehole data [1,2], knowledge on the development of permafrost on morphologically active or recently formed surfaces remains limited. Based on the available information, a conclusion may be drawn that despite the warming climate, permafrost still aggradates in the ground exposed due to the retreating of the glaciers [3-5]. However, the evolution of permafrost seems more complicated in the case of fluvio-glacial sediments in the direct vicinity of the sea, where the land is thermally and chemically affected by the sea water [6-8]. It can be assumed that the sediments filling the Svalbard bays and fjords in recent decades are subject to permanent freezing; however, this process is limited from the seaside by the thermal and chemical impact of sea water. Therefore, the main objective of this study was to attempt the identification of conditions stimulating the development of permafrost on the example of outwash fans in a coastal area, with a focus on their morphology and evolution stages.

The sandurs used as examples in this study, named Elveflya and Nottingham, are situated in the south-west part of the Spitsbergen. The fast retreat of glaciers in this region $[9,10]$ is due to dynamic morphological changes of the coastal zone [11-13]. The coast is subject to glacio-isostatic uplift [14]. In the investigated area, no sub-sea permafrost was identified [15], unlike in other well-described depositional environments of the Arctic zone, e.g., the delta of the Mackenzie River [16,17] or the coast of Siberia [18-21]. The ground temperature monitoring system in Svalbard provides, however, solid evidence of an increasing thickness of the permafrost active layer [22-26].

The Werenskiold Glacier marginal zone, located in the Wedel-Jarlsberg Land, was selected for the study, as the age determination of fossil tundra and the analysis of photographs and maps produced since the beginning of the 20th century allow the identification of the evolution stages and datings of individual landforms present in the contemporary landscape. The ground in the vicinity of the research area is thermally monitored, but only up to $1.5 \mathrm{~m}$ depth [27].

The study includes a reconstruction of the evolution of outwash fans and a photointerpretationbased analysis of their shape. The classified images included orthophotomaps based on aerial photographs and LANDSAT satellite scenes. The occurrence of permafrost under the terrain surface was investigated with the use of electromagnetic induction. The study also includes a discussion of the age of the sandur surfaces in light of the already existing and newly performed radiocarbon dating results for the organic material found in the sediments. Explanation of the contemporary tendencies in the geomorphological processes active on the sandur surfaces was attempted on the basis of satellite radar data (Sentinel-1A/1B) processed with the Small Baseline Subset (SBAS) method [28]. The satellite data provided information on vertical ground movements in the summer period, in which no snow is present on the terrain surface [29-31]. Due to the selected research methods, detailed sedimentological analysis of the investigated surfaces was not performed. This fact differentiates the present study from the majority of publications on outwash plains (e.g., [32-36]).

\section{Methods}

The confronted research problem required an interdisciplinary approach (Figure 1, Table 1). The morphological characteristics of the Elveflya sandur were described on the basis of photointerpretation. The two used orthophotomaps were based on aerial photographs of the Norwegian Polar Institute, made during flights performed in 1990 and in 2011. The first orthophotomap was prepared by Kolondra [37] in a $0.8 \times 0.8$ resolution and was available in print. The second map, in a 0.4 $\times 0.4 \mathrm{~m}$ resolution, was prepared in the Agisoft PhotoScan Professional Edition software. Using the orthophotomaps, the color of the terrain was analyzed with the ISO Cluster Unsupervised Classification tool implemented in the ArcMap software (ESRI), using a method known as ISODATA [38-40]. The classification included five and eight classes, in order to obtain maps with various degrees of detail. The same method was used to classify the true color images obtained from the LANDSAT scenes (Table 2). 


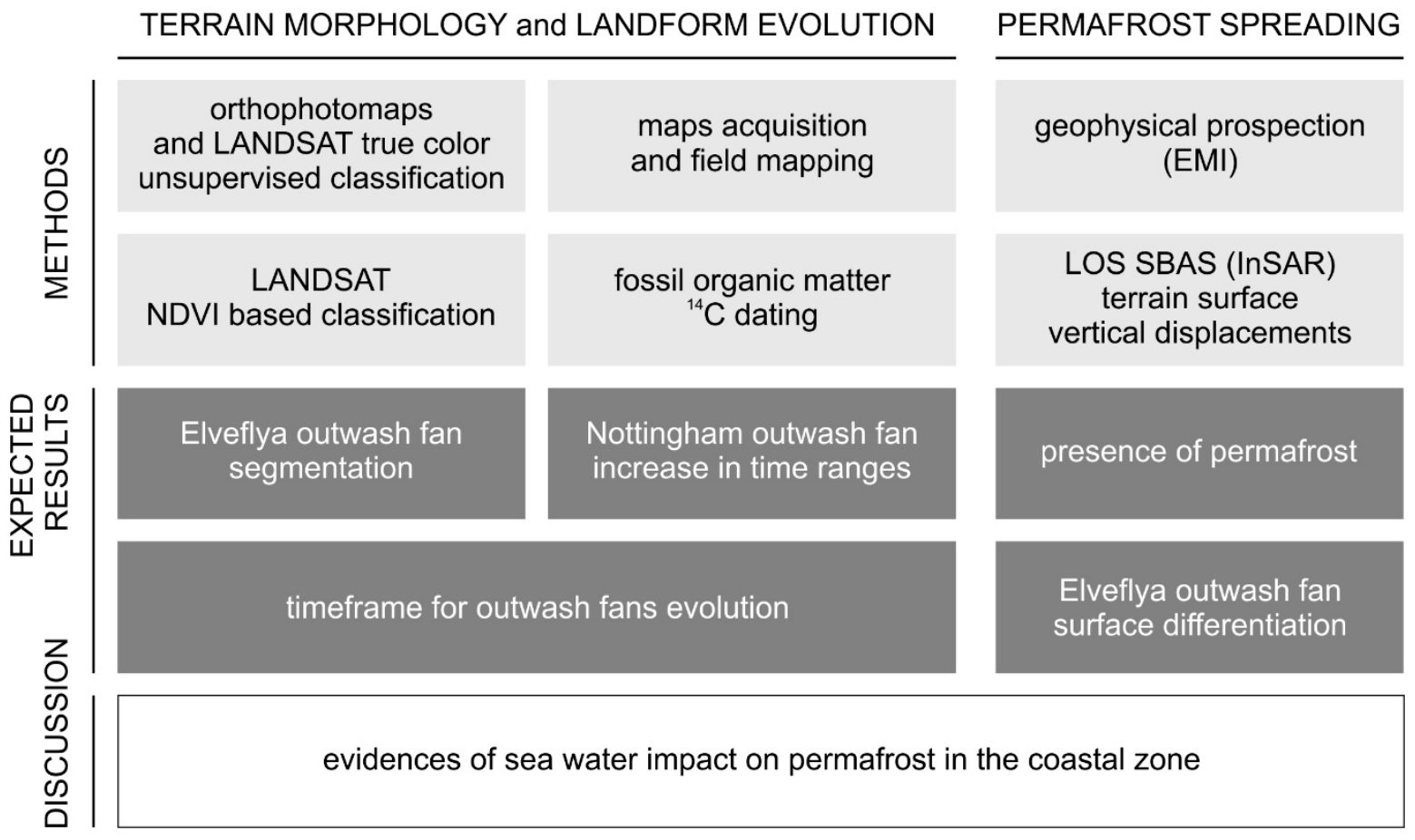

Figure 1. A simplified investigation scheme presented in a block diagram.

Table 1. Summary of the remote sensing data.

\begin{tabular}{ccccc}
\hline Type of Data & Time & Methods & Results & Application \\
\hline Orthophotomaps & 1990,2011 & True color ISO & $\begin{array}{c}\text { outwash fan } \\
\text { segmentation }\end{array}$ & landform evolution \\
\hline LANDSAT & $1985-2017$ & True Color, NVDI & $\begin{array}{c}\text { outwash fan } \\
\text { segmentation }\end{array}$ & landform evolution \\
\hline Geophysical & 2017 & EMI & $\begin{array}{c}\text { electrical resistivity } \\
\text { of ground }\end{array}$ & $\begin{array}{c}\text { permafrost } \\
\text { identification }\end{array}$ \\
\hline InSAR & 2018 & LOS SBAS & $\begin{array}{c}\text { vertical } \\
\text { displacement of } \\
\text { terrain surface }\end{array}$ & surface processes \\
\hline
\end{tabular}

Table 2. Satellite images used in true color and Normalized Difference Vegetation Index (NDVI) interpretations.

\begin{tabular}{ccccc}
\hline Lp. & Series & Sensors and Resolution & Date & Time \\
\hline 1. & L7 & ETM $+(30 \mathrm{~m})$ & $2002-07-10$ & $11: 28$ \\
2. & L7 & ETM $+(30 \mathrm{~m})$ & $2010-08-24$ & $11: 38$ \\
3. & L8 & OLI $(15 \mathrm{~m})$ & $2017-08-3$ & $11: 46$ \\
\hline
\end{tabular}

The LANDSAT scenes were also used to calculate the normalized difference vegetation index (NDVI) and to evaluate plant succession [41]. The indicator was obtained with the use of the raster calculator, on the basis of the following equation [42]:

$$
N D V I=\left(\frac{I R-R}{I R+R}\right)
$$

where $I R$ is the infrared band: In Landsat 7 band no. 4 and in Landsat 8 band no. 5 ; and $R$ is the red band: In Landsat 7 band no. 3 and in Landsat 8 band no. 4. The classification results were 
subsequently averaged in order to eliminate variations of the obtained NDVI resulting from seasonal changes observed in the satellite images.

The development stages of the outwash fans were identified by analyzing photographs from 1918 and 1936 (npolar.no/bildearkiv/) and maps. The time frame for the initial formation stages of the Elveflya sandur were established by dating fossil organic sediments. The study includes a comparison of the ${ }^{14} \mathrm{C}$-based dating results obtained in the past by other researchers $[43,44]$ with the recent datings of fossils found inside push moraines in front of the Werenskiold Glacier end moraine.

The growth of the second sandur currently developing at the Nottingham bay was reconstructed on the basis of 14 LANDSAT scenes, 7 obtained during high tide and 7 obtained during low tide. The subsequent interactive supervised classification involved division into three classes (sandur surface, slurry seawater, and clear seawater). The sandur surface and the range of sediment suspended in sea waters were vectorized in individual photographs. In order to obtain the mean sandur range in the various tidal conditions reflected in the few available satellite images (low tides, high tides), the ranges were averaged for the periods of 1986-2000, 2000-2010, and 2010-2017.

The near-surface ground layer was examined in August 2017 with the use of electromagnetic induction (EMI) measurements to confirm the existence of permafrost [45]. The examinations were based on the fact that rocks cooled to temperatures below $0{ }^{\circ} \mathrm{C}$ lose their ability to conduct an electric current [46]. An assumption was made that resistivities near or over $1 \mathrm{k} \Omega . \mathrm{m}$ may be characteristic of frozen ground, as the phenomenon is interpreted in more frequently used electrical resistivity tomography [47-49]. However, a review of literature reports on the electrical resistivity of permafrost in the coastal zone [6] indicates that it is difficult to use limit values outside of laboratory conditions. During field tests, it is important to identify significant differences in the resistivity values revealed between frozen and unfrozen ground [50]. The measurements were carried out with an electromagnetic conductivity meter CMD-Explorer (GF Instruments, Brno). The device is used to measure apparent conductivity and inphase [51,52]. It is tubular in shape and portable, and contains both transmitter and receiver coils, which allow simultaneous measurements of electrical conductivity at three depths b.g.l. (the settings were at 2.2, 4.2 , and $6.7 \mathrm{~m}$ ). The measurements were carried out in selected profiles, at 5-m intervals. The results, calculated into apparent resistivity for comparison with published values derived from DC measurements, were processed in the RES2DINV software (Geotomo, Malaysia). The software served to perform geophysical inversion with the use of the L2-norm function [53]. The data were visualized for the 5th iteration with the use of a topographic correction to allow for the terrain surface.

The existence of permafrost in the investigated area may be further evidenced by the LOS (line of sight) displacements of the terrain surface. The spatial distribution of this process was analyzed with the SBAS method. The study was based on data provided by the Sentinel-1A/1B satellite. The analysis of LOS displacement in the direction of the satellite was based on data from two paths: Path 14 of ascending-orbit geometry and path 154 of descending-orbit geometry. The interferometric wide swath (IWS) images used in the study cover an area corresponding to the research area, have identical resolution, polarization, and regular flight intervals (every 6 days). The analysis included only images taken in the summer (between the end of May and mid-October 2018), when the analyzed surface is not covered with snow. Table 3 shows detailed Synthetic Aperture Radar (SAR) data used in the calculations. 
Table 3. S ynthetic Aperture Radar (SAR) scene data acquisition: basic information.

\begin{tabular}{ccccccc}
\hline $\begin{array}{c}\text { SAR } \\
\text { Mode/Geometry }\end{array}$ & $\begin{array}{c}\text { Frame/ } \\
\text { Polaryzation }\end{array}$ & Path & $\begin{array}{c}\text { Observation Period } \\
\text { (First-Last Selected } \\
\text { Scenes) }\end{array}$ & $\begin{array}{c}\text { Revisit } \\
\text { Time }\end{array}$ & $\begin{array}{c}\text { Number of } \\
\text { Selected Scenes }\end{array}$ & $\begin{array}{c}\text { LOS } \\
\text { (Orientation/ } \\
\text { Incidence Angle) }\end{array}$ \\
\hline $\begin{array}{c}\text { Interferometric } \\
\text { Wide Swath (IWS) } \\
\text { Ascending }\end{array}$ & $\begin{array}{c}251 \\
\mathrm{HH}+\mathrm{HV}\end{array}$ & 14 & $2018-05-24-2018-10-15$ & 6 days & 25 & $344.0^{\circ} / 43.4^{\circ}$ \\
\hline $\begin{array}{c}\text { Interferometric } \\
\begin{array}{c}\text { Wide Swath (IWS) } \\
\text { Descending }\end{array}\end{array}$ & $\begin{array}{c}333 \\
\mathrm{VV}+\mathrm{HV}\end{array}$ & 154 & $2018-05-22-2018-10-13$ & 6 days & 25 & $215.0^{\circ} / 38.8^{\circ}$ \\
\hline
\end{tabular}

In total, 25 scenes were analyzed for each path, covering the 4-month time period. Coherence analysis was based on SLC (single look complex) image processing. The interferograms were prepared in the GMTSAR environment [54]. The topographic correction in the calculations of the interferograms was introduced according to Massonnet et al. [55], using an SRTM digital elevation model (DEM) [56] with a resolution of $30 \mathrm{~m}$. A total of 174 interferograms were processed for the two paths (73 for path 14 and 101 for path 154) within a narrow time range, between 6 and 24 days, and spatial range, between 7 and $164 \mathrm{~m}$ (Appendix A: Table A1 and Figure A1).

The interferograms were unwrapped with the use of the Statistical-Cost, Network-Flow Algorithm for Phase Unwrapping (SNAPHU) [57]. Short time intervals between successive passes and strictly controlled orbital data of the Sentinel-1 satellites, in combination with favorable (almost flat) terrain conditions and with the lack of vegetation result in highly coherent interferometric phase in the investigated area. The interferometers were filtered with the use of the Goldstein filter to eliminate the noise level [58], unpacked with a minimal flow algorithm, and subsequently geocoded with a spatial resolution of $200 \mathrm{~m}$. The influence of the atmosphere was reduced by using a data-based approach, in which a linear relationship is found between the residual phase and the SRTM topography [59]. The data grouping used in the calculations is a simple averaging of all selected interferograms weighed with time intervals between the scenes, in order to reduce atmospheric interference by assuming effects in the troposphere non-correlated in time [60]. Calculations of the topographic, atmospheric, and deformation components were performed with the use of spatial and time filters [61].

The SBAS-calculated displacements correspond to single-dimension values of relative changes along the LOS over the 4-month period of ground thawing. In each of the processed paths, the first scene is a point of reference for the calculated displacement values (Appendix A: Figure A2). The dates selected for the analysis vary by 2 days (May 22 and 24) for each path. This introduces relativity to the displacement analysis, but at the same time allows the calculation results to be presented in a uniform manner. Vertical displacements are illustrated in this article only, with single differential models showing the general regularities and spatial location of the seasonal surface displacements.

\section{Study Area}

The study was carried out in the Wedel-Jarlsberg Land, in the south-west coast of the Spitsbergen, near the Stanislaw Baranowski Polar Station of the University of Wroclaw (N 77 $04^{\prime} 15,6^{\prime \prime}$, E $15^{\circ} 10^{\prime} 42,5^{\prime \prime}$ ). The average annual temperature recorded in this region between 2005 and 2011 was $-1.7^{\circ} \mathrm{C}$, with March as the coldest month $\left(-10.3^{\circ} \mathrm{C}\right)$, and July as the warmest month at $5.4^{\circ} \mathrm{C}$ [61]. The current climate warming results in the highest rise of temperatures in the fall and winter periods [62-64]. The average annual total precipitation, as observed in the period of 1979-2009 for the neighboring Hornsund station, was $434.4 \mathrm{~mm}$, with maximum precipitation in August (64.4 mm) [65]. Snow covers the terrain surface on an average of 244 days per year [66].

The study area covered the Werenskiold Glacier marginal zone (Figure 2a, Figure 3). The terminus zone of the glacier retreated between 1957-2013 by $1.2 \mathrm{~km}$ [67], with its average retreat rate being 25 $\mathrm{m} \cdot$ year $^{-1}\left(50,000 \mathrm{~m}^{2} \cdot \mathrm{year}^{-1}\right)$. In front of the end moraine, Kvisla-a proglacial river-formed on an uplifted shore platform of a large $\left(5.57 \mathrm{~km}^{2}\right)$ sandur: Elveflya. It is built of fluvio-glacial sediment, consisting of single boulders, cobbles, gravels, and sandy beds deposited in the conditions of an arctic 
braided river. Particle size is decreasing in the NE-SW direction (in accordance to slope). The fan apex is cut by abandoned channels of the Kvisla river up to a $5 \mathrm{~m}$ depth. The fan surface is also varied by tors, which formed skerries in the past.

The capturing of the Kvisla waters by the second of the major proglacial rivers resulted in significant hydrographic changes and the Elveflya sandur stopped developing. All of the glacial waters were directed into the single river channel of the Werenskiold river into the Nottingham bay. The transported bed load formed a delta in the bed of the bay, and the constant aggradation of the bed affected the moving of the coastal zone. Currently, a new outwash fan is developing in the land part of the coastal zone. For the purpose of this study, it will be referred to as the Nottingham sandur. The time frames for the processes analyzed here will be discussed in the analytical section dedicated to the dating of sediments and landforms in the Werenskiold Glacier marginal zone.

Water discharge in the Werenskiold river has been measured in a number of campaigns since the 1970s. The flow changes during the year, being dependent on ablative and solar factors [68]. In the ablation seasons of 2007-2010, the intensity of the flow was on average between 6.11 (2010) and 9.05 $\mathrm{m}^{3} \cdot \mathrm{s}^{-1}$ [69], and the maximum flow could exceed $30.66 \mathrm{~m}^{3} \cdot \mathrm{s}^{-1}$. Annual runoff from the Werenskiold Glacier catchment area, as identified in measurements spanning the period of 2007-2012, was between 56.37 (2007) and 98.71 million $\mathrm{m}^{3}$ (2012) [70].

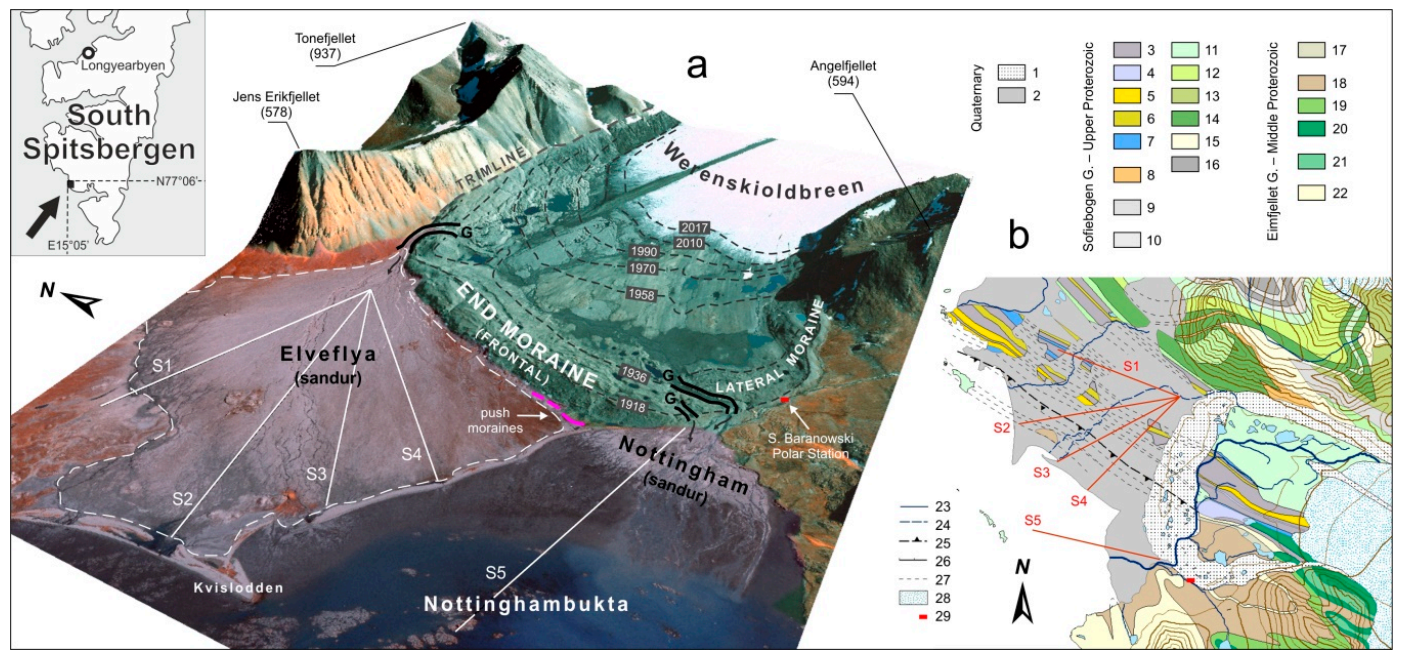

Figure 2. Study area: (a) oblique view; glacier terminus after Ciężkowski et al. [67], modified; (b) geological sketch based on Czerny et al. [71], simplified: Quaternary; 1-moraines, 2-fluvial deposits, ground moraine deposits and marine shore deposits; Upper Proterozoic, Elveflya Formation; 3-marble-quarzite and granite-quarzite metaconglomerates, 4-gray calcite marbles, 5-yellow quarzites and quartzitic schists, 6-mica-carbonate-quartz schists (including dropstones), 7-black chloritoid-bearing quartz-paragonite-muscovite schists; Slyngfjellet Formation; 8-Yellowish muscovite-carbonate-quartz schists; Gashamna Formation; 9-black phyllites; Hoferpynten Formation; 10-gray dolostones and black calcite marbles; Jens Erikfjellet Formation; 11-laminated greenstones with epidotite lenses, 12-black greenstones, 13-greenstones with metachert intercalations, 14-greenstones, 15-pink calcite marbles, 16-greenschists and carbonate-chlorite-quartz schists; Middle Proterozoic, Eimfjellet Group, 17-chlorite and muscovite-chlorite diaphthoritic schists; Bratteggdalen Formation; 18-mica schists with intercalations of amfibolites, metarhyolites, quartzites and laminated quartz-feldspar felses, 19-amphibolites interbedded with chlorite and biotite schists, 20-black coarse-grained amphibolites; Skalfjellet Formation; 21-amphibolites with anorthositic metagabbro enclaves; Gulliksenfjellet Formation; 22-white and green quartzites; 23-rivers, 24-abandoned river channels, 25-thrust faults, 26-faults, 27-geological boundaries, 28-glacier ice, 29-Stanisław Baranowski Polar Station; G-gorges, S1-S5-electromagnetic induction (EMI) sections. 

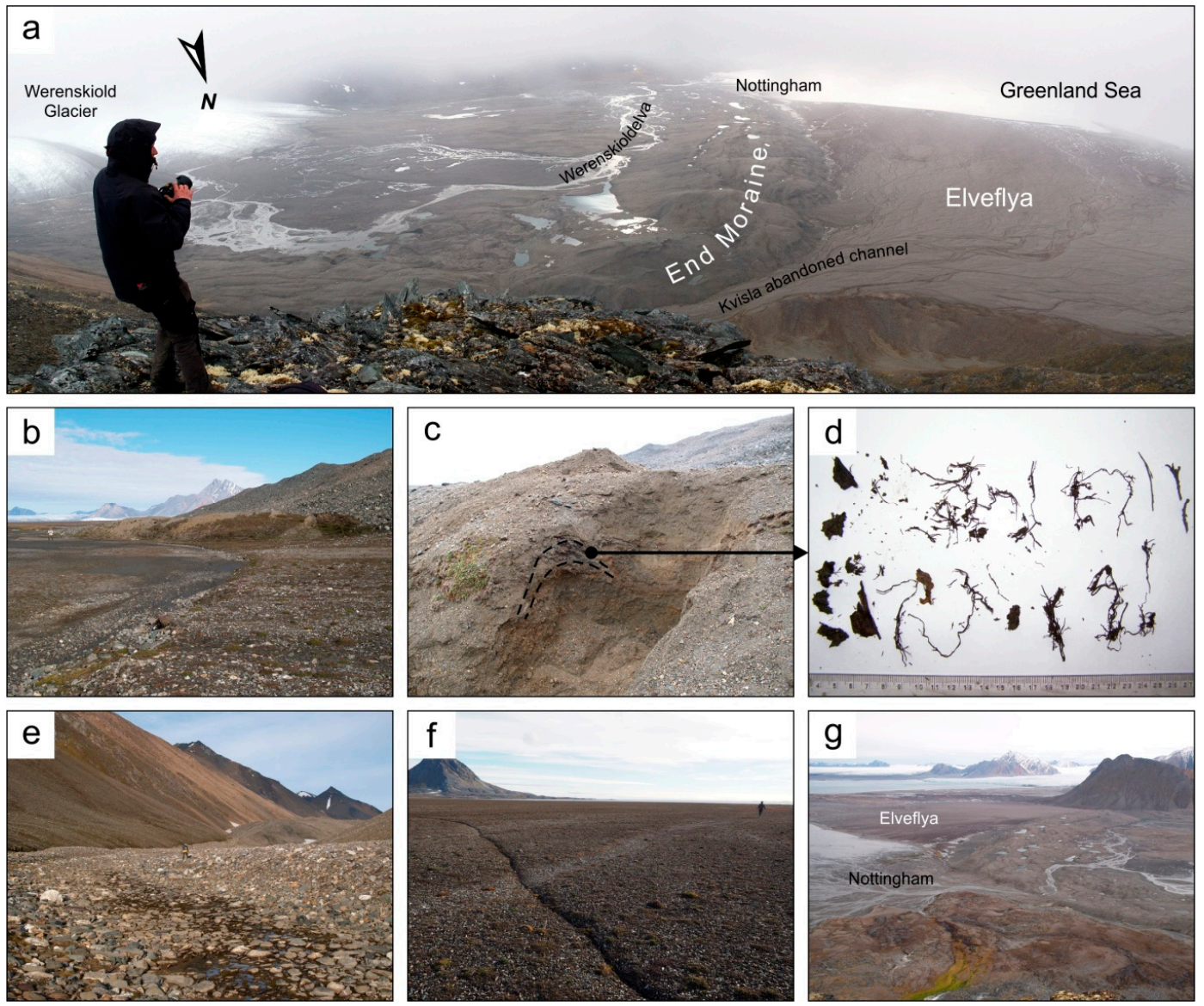

Figure 3. Landforms in the research area: (a) panoramic (distorted) view from the Mt. Jens Erik, (b) the biggest push moraine in the front of the Werenskiold Glacier end moraine, (c) cross-section of the push moraine with a raised and deformed layer of fossil tundra, (d) fossil tundra in examples of Saxifraga and Salix polaris collected from deformed layer visible in the photo c, (e) the upper part of the Elveflya fan and abandoned channel of the Kvisla river, (f) linear cracks on the Elveflya surface, and (g) view from the South to the North.

The surface of the Werenskiold Glacier catchment area which feeds the runoff of the Werenskiold river is $44.1 \mathrm{~km}^{2}$ (61\% glacierized). Its base consists of lithologically varied rocks of the Proterozoic [71], which include silicates of various metamorphic grade (gneisses, shales, phyllites, various metasedimentary rocks with well-preserved relics of their original structure), carbonate rocks, and mixed rocks (Figure $2 b$ ). The redeposited products of their weathering and mechanical destruction by the glacier form an end moraine and the surface of the Elveflya and Nottingham sandurs. Locally, on the surface of the Elveflya sandur, heavily weathered bedrock shales emerge from the fluvio-glacial sediments, forming tors of limited height or short ridges running in the NW-SE, structurally determined, direction.

The deglaciated surfaces in the study area are commonly considered to be frost penetrated. According to previous studies [72-75], during the summer period, the ground in the area thaws to an average depth of 100-115 cm, while the greatest thickness of the permafrost active layer $(230 \mathrm{~cm})$ was found in the marine sands and gravels [76]. Recent thermal measurements of the near-surface ground parts performed in the vicinity of the study area indicate that in the summer, the tundra-covered land surface may reach temperatures above $20^{\circ} \mathrm{C}$ [77], and the temperature of the ground at the depth of $1.5 \mathrm{~m}$ may reach up to $4.3^{\circ} \mathrm{C}$ in August [27]. Based on geophysical imaging, a conclusion may also be drawn that the permafrost base in the coastal zone is additionally influenced by the thermal currents and salination of the seawater $[6,7]$. 


\section{Results}

\subsection{Outwash Plains Morphology}

The outwash fan of the Elveflya is $3200 \mathrm{~m}$ long $(\mathrm{E}-\mathrm{W})$ and $3000 \mathrm{~m}$ wide $(\mathrm{N}-\mathrm{S})$. It has a surface of $5.57 \mathrm{~km}^{2}$ and a circumference of $11.9 \mathrm{~km}$. On the west and south west, it borders the Greenland Sea. A line of coastal lakes stretches in the onshore part of the coast, behind a belt of storm berms. This is where the lowest point of the sandur (1.5 m b.s.l.) is located. Its surface rises to the east, where it reaches $30 \mathrm{~m}$ a.s.l at the point of origin of the fan located at the former Kvisla gorge. The average fan elevation is $5.6 \mathrm{~m}$ a.s.l. In total, $11.5 \%$ of its surface is covered by depressions. In total, $32 \%$ of the fan does not rise higher than $1 \mathrm{~m}$ a.s.1., 51\% higher than $4 \mathrm{~m}$ a.s.1., and 95\% higher than $19 \mathrm{~m}$ a.s.1. Based on the unsupervised classification (Figures 4 and 5), six fans (A-F in Figure 6) were identified. Not all of them are equally visible on the two analyzed orthophotomaps and on the LANDSAT scene. For example, fan D is best visible on the Kolondra orthophotomap [37]. The division of the surface into five classes allowed identification of the fans, and the division into eight classes a precise estimation of their range.

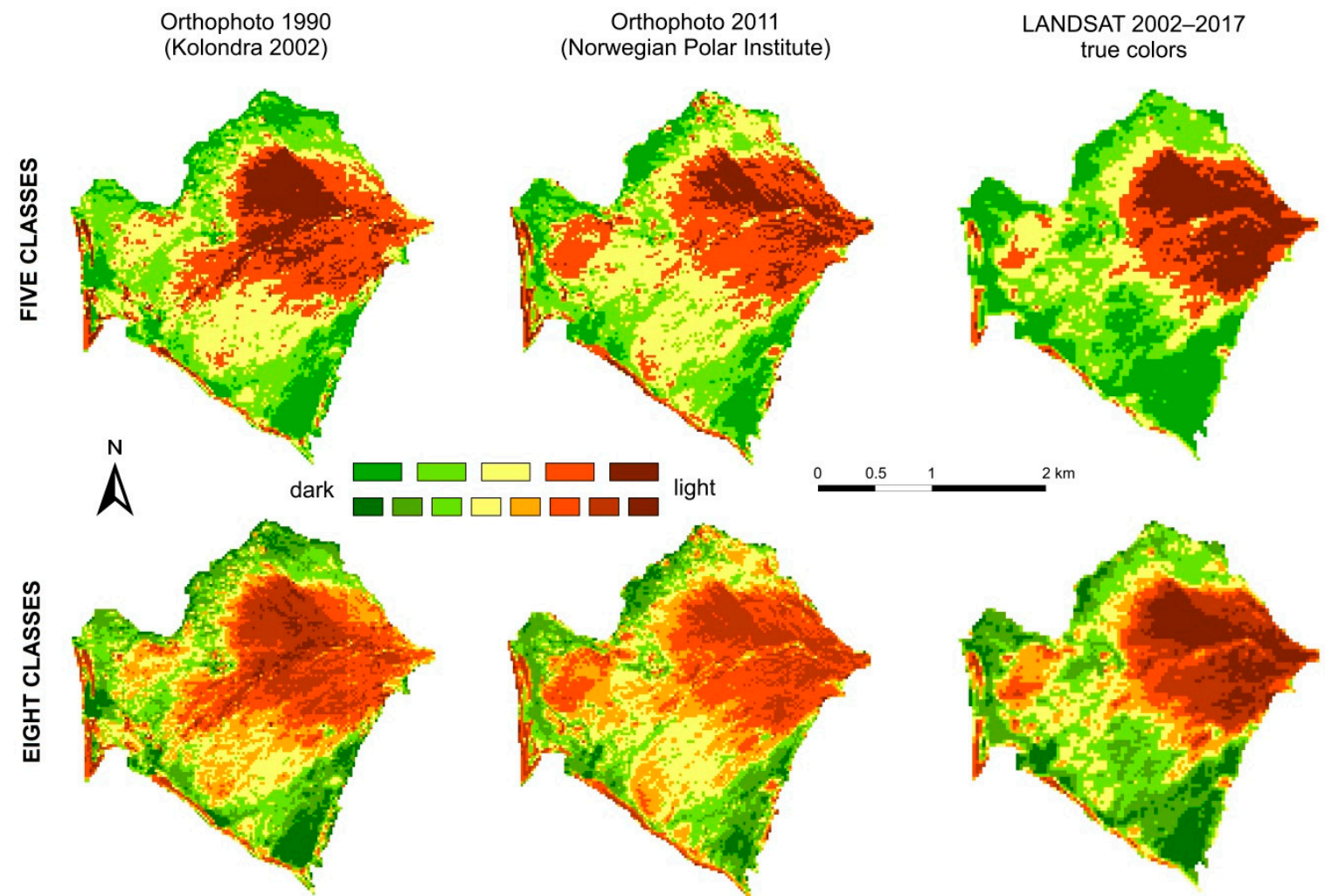

Figure 4. Results of the Elveflya outwash fan photointerpretation.

The colors of the Elveflya surface indicate three types of differences. The first type is the difference between the light-colored proximal end and the dark-colored distal end of the fan. This is due to the age of the individual development stage-younger microfans are lighter, as they are formed of less weathered (mechanically and chemically) gravels and not covered with pioneer tundra vegetation. A significant brightness difference between the two areas indicates that for a longer period of time the distal end of the fan has not been subjected to intensive depositions of fluvio-glacial sediments. In situ observations confirm this fact. 

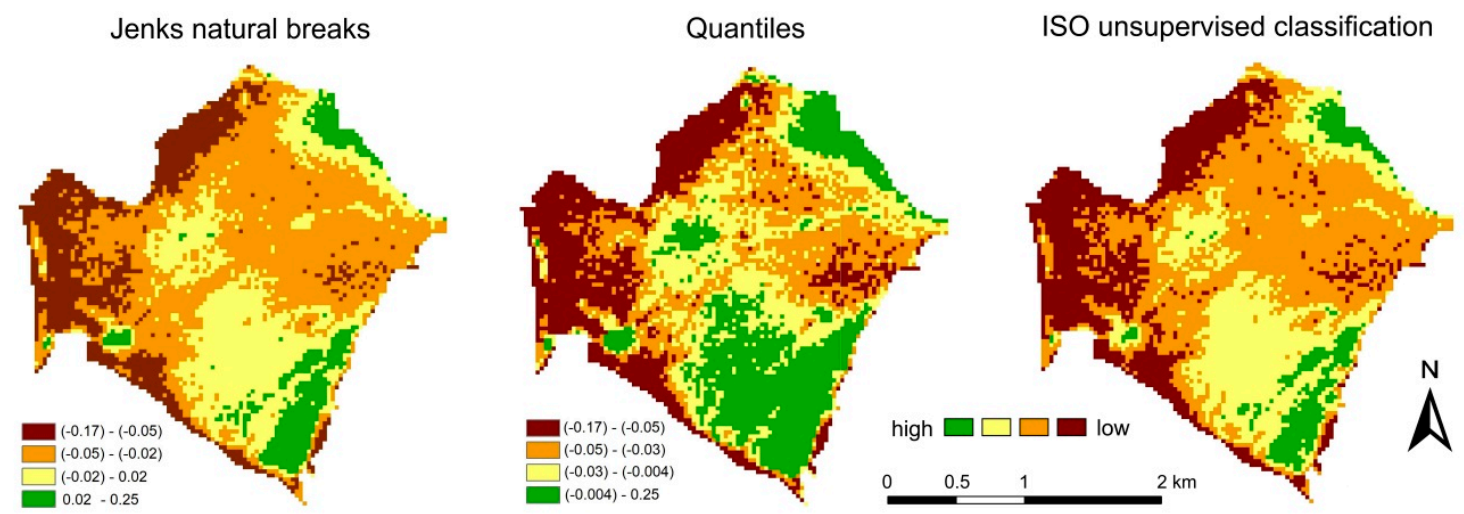

Figure 5. Normalized Difference Vegetation Index (NVDI) analysis of the Elveflya outwash fan.
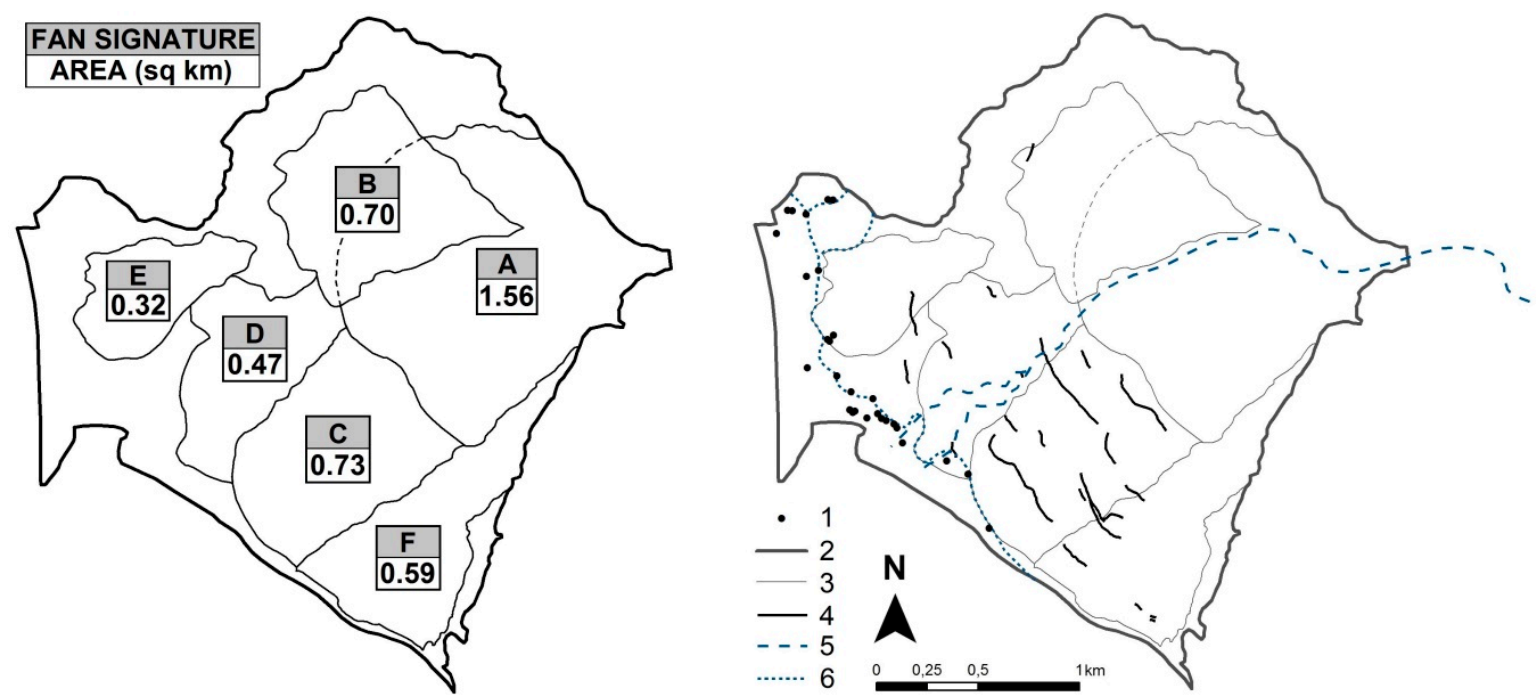

Figure 6. Microfans of the Elveflya surface (A-F): 1-driftwood, 2-the Elveflya surface, 3-microfans range, 4-linear cracks, 5-last braided channel of the Kvisla, 6-previous shoreline.

The second difference is manifested in the proximal and distal parts (Figure 6). The proximal part may be divided into the youngest surface (A), which is deposited on the older fan (B). Both fans have a similar brightness, but fan a noticeably extends further to the north-west from fan B. Both fans consist of slightly weathered debris represented by gravels of various grain sizes up to boulders. On the basis of its brightness, the distal part of the fan is divided into surfaces corresponding to three evolution phases (C, D, and E), with the division being not as clear as in the case of the proximal part of the Elveflya. The $C$ and $D$ surfaces are not visible in the resultant reclassification layers from the LANDSAT scenes. In addition, their color is almost identical and therefore their shape remains their main characteristic feature. The south-extending $C$ tongue is in the shape of a fan with a dark-colored inner area and a light-colored outer area. The D surface, on the contrary, has a shape of an irregular tongue along the last Kvisla bed, and is supported on the stone outcrops located in the central part of the Elveflya. It is impossible to precisely identify which morphogenetic phase occurred later, although the fact that fan D has a shape resembling the last Kvisla bed may indicate its younger age. However, the Kvisla river may have eroded into the already existing fan. The boundary between fans $C$ and $D$ is not clear. The E surface is positioned in the northern part of the Elveflya and is related to the flow of water in a recess located at the edge of the sandur. Fan $\mathrm{E}$ is unique in being exposed differently (to the south) and having a greater brightness than the surrounding.

The third type of difference observed during the photointerpretation is that wet areas exist on the northern and eastern edges of the sandur. Fan F, which has been identified on the basis of this 
difference, is located under the slope of the end moraine and is not related to the activity of the Kvisla river. It is the effect of sediment slopewash from the moraine. The darker color is due to the ground moisture, limited dynamics of the environment, and the presence of tundra.

The NDVI for the whole fan is very low and with little diversity (Figure 5), being characteristic of poor tundra vegetation, with the average at $(-0.025)$. The index reaches positive values only in the northeastern and eastern parts, indicating the stability of their surfaces. The highest NDVI values are reached on surface $\mathrm{F}(+0.023)$, which confirms that the environmental conditions are different in this location. The lowest NDVI values are recorded in the depressions in the north and in the west, which is related to water frequently occurring in these land parts.

Photointerpretation analysis allowed 22 cracks to be distinguished in the ground (Figure 6), in the distal part of the Elveflya sandur. Their length is between 15 and $580 \mathrm{~m}$. They have an arch shape corresponding to the shape of the shoreline. Neither in-situ research nor the photointerpretation confirmed the existence of a second perpendicular system of cracks.

The Nottingham outwash fan is approximately $1000 \mathrm{~m}$ in length and $1500 \mathrm{~m}$ in width in its distal part. Measuring its precise dimensions is impossible, as the area is covered by sea waves. The fan apex reaches $6.5 \mathrm{~m}$ a.s.l., but $80 \%$ of the fan surface is located below $1 \mathrm{~m}$ a.s.l. Its inclination is $2^{\circ}$ at the apex and decreases in the fan toe to less than $1^{\circ}$. In the years 1985-2000, the land surface area of the fan was on average $0.52 \mathrm{~km}^{2}$; in the years 2000-2010, it was $0.60 \mathrm{~km}^{2}$; and in the years 2010-2017, it was $0.85 \mathrm{~km}^{2}$, increasing over the whole investigated period by $39.5 \%$. Over the whole investigated period, the average growth rate of the sandur surface area was $13,400 \mathrm{~m}^{2} \cdot \mathrm{year}^{-1}$ and increased from $5700 \mathrm{~m}^{2} \cdot$ year $^{-1}$ over the period of $1985-2000$ to $24,900 \mathrm{~m}^{2} \cdot$ year $^{-1}$ over the period of 2010-2017, which is a fivefold increase of the fan aggradation rate (Figure 7). In order to identify the surface area of the sediment temporarily flooded by the sea, it was measured that during low tides $(0.3-0.4 \mathrm{~m})$, a surface area of $0.60 \mathrm{~km}^{2}$ remains above sea level, and during high tides $(1.2-1.3 \mathrm{~m})$ the surface area above the sea level is $0.71 \mathrm{~km}^{2}$, which means that $14.7 \%$ of the surface of the sandur is temporarily covered by the seawater.
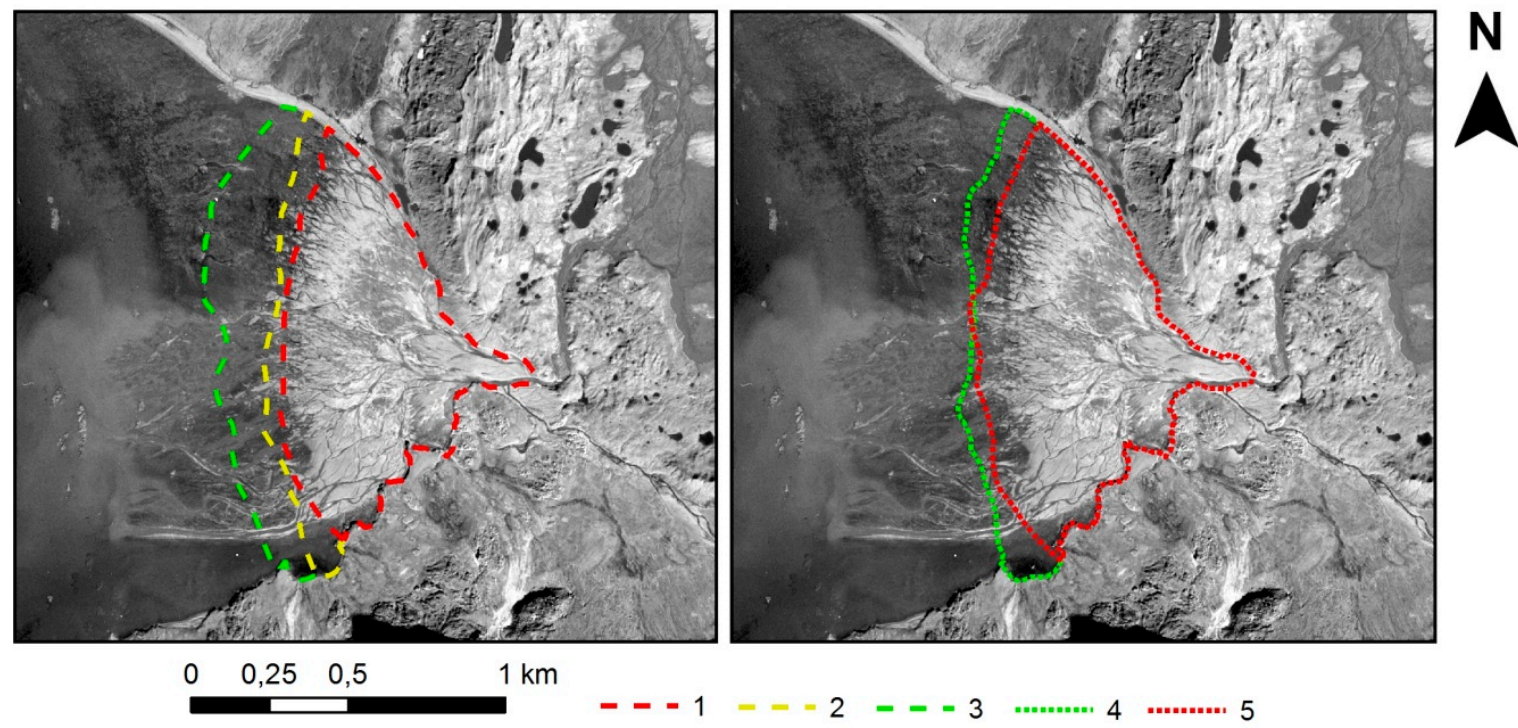

Figure 7. Evolution of the Nottingham outwash fan averaged over periods: (1) range in 1985-2000, (2) range in 2000-2010, (3) range in 2010-2017, (4) low tides (0.4-0.4 m), and (5) high tides (1.2-1.3 m).

All of the fan is cut with the channels of a braided river. The photointerpretation did not reveal any significant color differences on this surface. The NDVI values approximating one indicate a complete lack of vegetation on the surface of the fan. The only differences in the brightness of the ground are due to its temporary wetness in the dynamically changing seashore. The lack of brightness differences indicates that the deposition process is continuous, and no catastrophic phenomena occurred. 


\subsection{Landscape Evolution}

The evolution of the investigated sandurs is the direct result of the ablation of the Werenskiold Glacier and climatic factors. It is also dependent on the modifications of glacial and fluvio-glacial landforms. Landscape evolution may be reconstructed from the datings of organic remains found in the zone. Datings of shells found in marine gravels buried under glacial till between the end moraine and the current glacier terminus (Figure 8) indicate that this region formed the bottom of the bay already in the Atlantic period. Datings of fossil tundra found under glacial till [43] demonstrate that in the Subatlantic age, the area was most likely already raised above sea level. New datings obtained by the authors on the deformed organic layer inside the push moraines in front of the end moraine of the Werenskiold Glacier indicate the same age of the fossil tundra. This observation proves that the push moraines were shaped during the Little Ice Age (LIA). The dating results of the acquired organic material, represented mostly by Saxifraga and Salix polaris, are presented in Table 4.

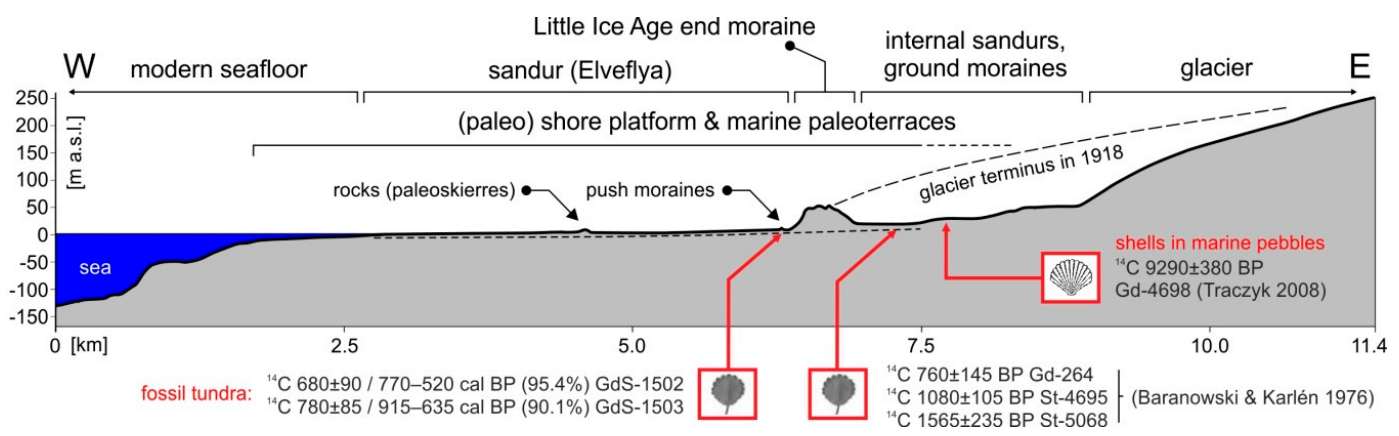

Figure 8. Landforms evolution in the light of fossil organic deposits dating.

Table 4. Dating of the fossil tundra from a push moraine layer.

\begin{tabular}{cccc}
\hline No & $\begin{array}{c}\text { Age }{ }^{14} \mathbf{C} \\
\text { (BP) }\end{array}$ & $\begin{array}{c}\text { Calendar Age } \\
\text { (Calibrated)-Ranges 68\% }\end{array}$ & $\begin{array}{c}\text { Calendar Age } \\
\text { (Calibrated)-Ranges 95\% }\end{array}$ \\
\hline GdS-1502 & $680 \pm 90$ & $\begin{array}{c}690-620 \mathrm{cal} \mathrm{BP}(37.8 \%) \\
615-550 \mathrm{cal} \mathrm{BP}(30.4 \%)\end{array}$ & $770-520 \mathrm{cal} \mathrm{BP}(95.4 \%)$ \\
\hline GdS-1503 & $780 \pm 85$ & $780-655 \mathrm{cal} \mathrm{BP} \mathrm{(68.2 \% )}$ & $\begin{array}{c}915-635 \mathrm{cal} \mathrm{BP}(90.1 \%) \\
595-560 \mathrm{cal} \mathrm{BP}(5.3 \%)\end{array}$ \\
\hline
\end{tabular}

The Elveflya sandur evolved together with the formation of the end moraine and after its formation, i.e., until LIA. The runoff of ablative waters is through the Kvisla gorge, at the northern edge of the end moraine. The second runoff direction was formed by the Breelva (river), which cut the end moraine at its southern edge and flowed into the Nottingham bay. After 1936, when the terminus of the glacier retreated, the gorge was abandoned and the Breelva formed a new gorge, which remains active until present. The most important hydrographic change in this area was the capturing of the Kvisla waters by the Breelva after the degradation of the medial moraine, which separated the two catchment areas. This happened before 1970 [78], during one of the 1963-1969 summer periods. As a result of this capture, the surface runoff on the northern side of the moraine ceased and all of the runoff from the Werenskiold catchment area was directed into the Nottingham bay. The river formed by the joining of the Kvisla and Breelva rivers is called Werenskioldelva. The growth of the Elveflya sandur was stopped and instead a delta started to be formed in the bottom of the Nottingham bay. Its proximal part, which is presently always above the sea level, forms the Nottingham outwash fan analyzed in this study. 


\subsection{Permafrost Occurrence}

Electromagnetic measurements performed along five longitudinal sections (S1-S5) demonstrated significant variations in the electrical resistivity of the ground (Figure 9). Measurements carried out on the surface of Elveflya suggest that from the perspective of the geoelectric properties, the ground may be classified into two main parts: a part having resistivities approximating $1000 \Omega . m$ and a part having varied but lower resistivity values (typically $\rho<200 \Omega$.m). In Section 1, higher resistivity ( $\rho$ $>200 \Omega$.m) was recorded along a distance of one kilometer, with a considerable resistivity decrease (from $\rho>1000 \Omega . \mathrm{m}$ ) after the first $250 \mathrm{~m}$. In other sections (2, 3, and 4), a rapid resistivity decrease was recorded $1 \mathrm{~km}$ from the fan apex, from a level of approximately $1000 \Omega . \mathrm{m}$ to values lower than $200 \Omega$.m. In the proximal part of the sandur, where the highest resistivity values are recorded, these values decrease slightly at the terrain surface. Lower resistivity values, below $50 \Omega$.m, were measured in wet areas with no runoff.

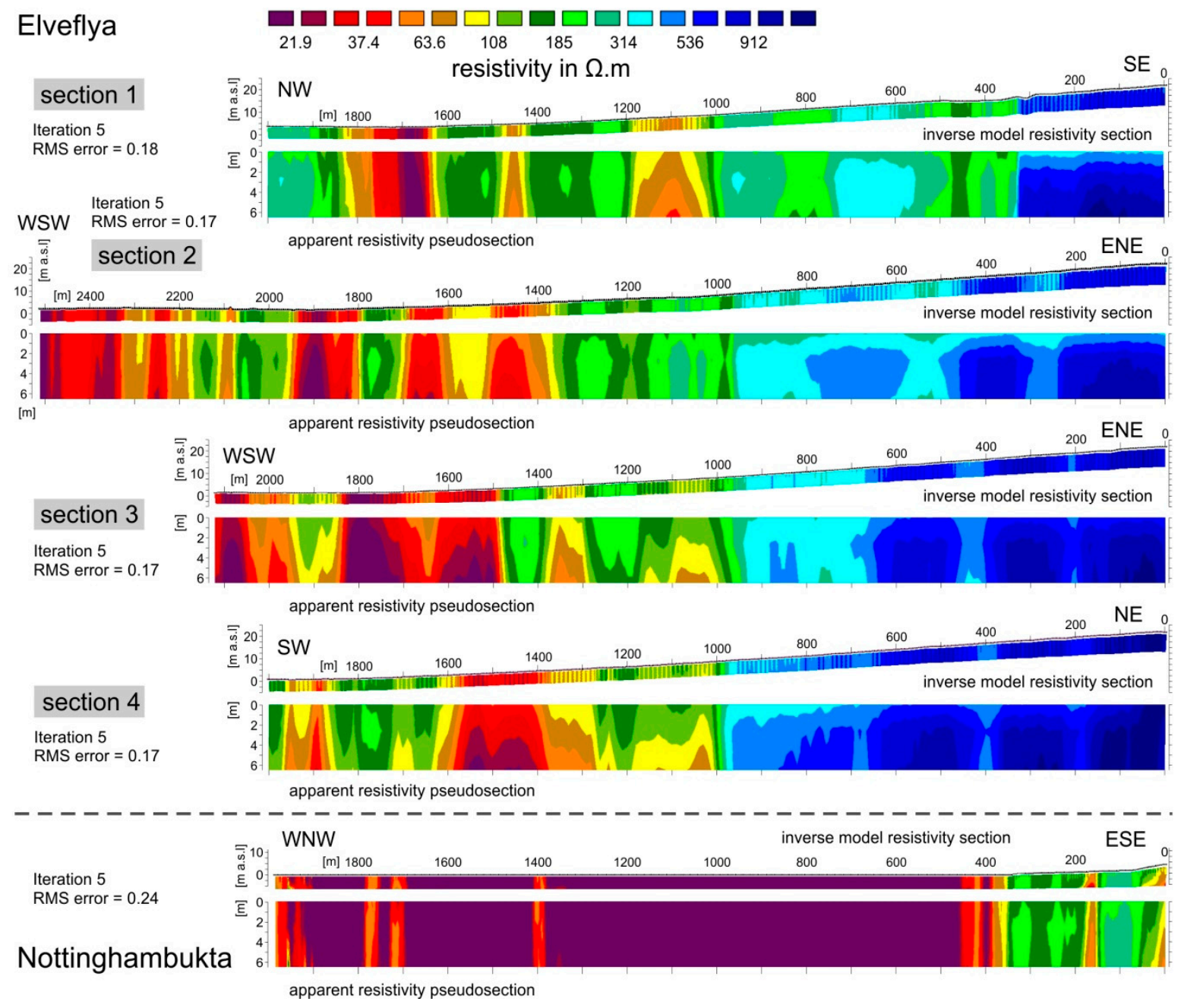

Figure 9. Electrical resistivity of the ground in Sections 1-5 (see Figure 2), the vertical exaggeration in the inverse models is 5 .

A resistivity close to or exceeding $1000 \Omega$.m may indicate permafrost. The distances correspond to the surfaces of the identified microfans A and B. Thus, the measurements confirm the existence of permafrost with an active layer at the surface in this part of Elveflya. In the remaining part of Elveflya, ground ice absence generates low true resistivity values. A similar situation is observed in the case of measurements on the Nottingham sandur and on the bottom of the Nottingham bay (Section 5). The main features of the investigated outwash fans are summarized in Table 5. 
Table 5. Main features of Elveflya and Nottingham outwash fans.

\begin{tabular}{|c|c|c|}
\hline & Elveflya & Nottingham \\
\hline $\begin{array}{l}\text { Contemporary deposition of } \\
\text { fluvioglacial sediments }\end{array}$ & No & Yes \\
\hline Age & $\begin{array}{c}<770-520 \text { years cal BP } \\
>1969\end{array}$ & $\begin{array}{l}<770-520 \text { years cal BP with a } \\
\text { sudden increase after } 1969\end{array}$ \\
\hline Size & $5.57 \mathrm{~km}^{2}$ & $0.85 \mathrm{~km}^{2}$ \\
\hline Heights & $1.5 \mathrm{~m}$ b.s.l. $-40 \mathrm{~m}$ a.s.1. & $0-8 \mathrm{~m}$ a.s.l. \\
\hline Slope & Up to $3.69^{\circ}$, average $0.86^{\circ}$ & Up to $2^{\circ}$, average less than $0.5^{\circ}$ \\
\hline Aspect & W-SW & $\mathrm{W}$ \\
\hline Current active processes & Eolian, cryogenic/degradation & Fluvial, marine/agradation \\
\hline Morphology & $\begin{array}{l}\text { Dry channels and bars of braided } \\
\text { river, bedrock outcrops, ground } \\
\text { crevices, storm ridges }\end{array}$ & $\begin{array}{l}\text { Active channels and bars of } \\
\text { braided river, tidal flat, skerries }\end{array}$ \\
\hline Surface color & varied & homogeneous \\
\hline NDVI & $\begin{array}{l}\text { Low to medium, presence of } \\
\text { pioneer vegetation }\end{array}$ & Close to -1 \\
\hline Electrical resistivity of ground & $\begin{array}{c}\rho>1000 \Omega . m \text { in the proximal part, } \\
\rho<200 \Omega . m \text { in the distal part }\end{array}$ & $\rho<200 \Omega . m$ \\
\hline Ground Ice/permafrost & Present in the proximal part (apex) & No evidence \\
\hline Other features & Driftwood on the coast & Single boulders \\
\hline
\end{tabular}

\subsection{Ground Surface Seasonal Dynamics}

Differential models obtained in the SBAS analysis clearly indicate vertical ground movements of the Elveflya surface (Figure 10 and Appendix A: Figures A3 and A4). Differential models show vertical movements from approximately +1 to $-5 \mathrm{~cm}$ (Appendix A: Figure A5), with the measurement error being no greater than $4 \mathrm{~mm}$ (Appendix A: Figures A6 and A7). At all analyzed time points, the Elveflya sandur is clearly divided into the proximal and the distal part. The surface of its proximal part is constantly stable in the ablation period, and only slightly raised above the level of the base model from the beginning of the ablative period. Its range covers microfans $\mathrm{A}$ and $\mathrm{B}$, identified in the photointerpretation. In the distal part of the fan, greater height differences are observed during the ablation period. From the beginning of July until the beginning of October, the area is subjected to subsidence. This effect is most evident in the belt along the last Kvisla channel and at the northern edge of Elveflya, where periodical ground water logging is observed.

Based on the obtained results, a conclusion can be made that the proximal part of the fan, close to the fan apex and Kvisla gorge across the Werenskiold Glacier moraine, is relatively stable. Vertical movements that locally exceed $5 \mathrm{~cm}$ are characteristic of the distal part of the investigated sandur, which neighbors the shore.

\section{Discussion}

The photointerpretation based on color differentiation of the surface of the Elveflya sandur, supported by the NDVI determination for LANDSAT scenes, allowed the identification of at least five separate Elveflya evolution phases. The identified microfans evolved as a result of changes in the location of the main Kvisla channel, after the runoff of the Werenskiold Glacier proglacial waters was formed at the northern edge of its end moraine. Field observations and datings allowed an observation that these changes occurred in the period between the advance of the glacier during LIA and the second half of the 1960s, when the runoff of surface waters in the Kvisla river ceased. The sixth microfan (F) 
identified in the Elveflya surface evolved owing to the water flowing down from the end moraine of the Werenskiold Glacier.

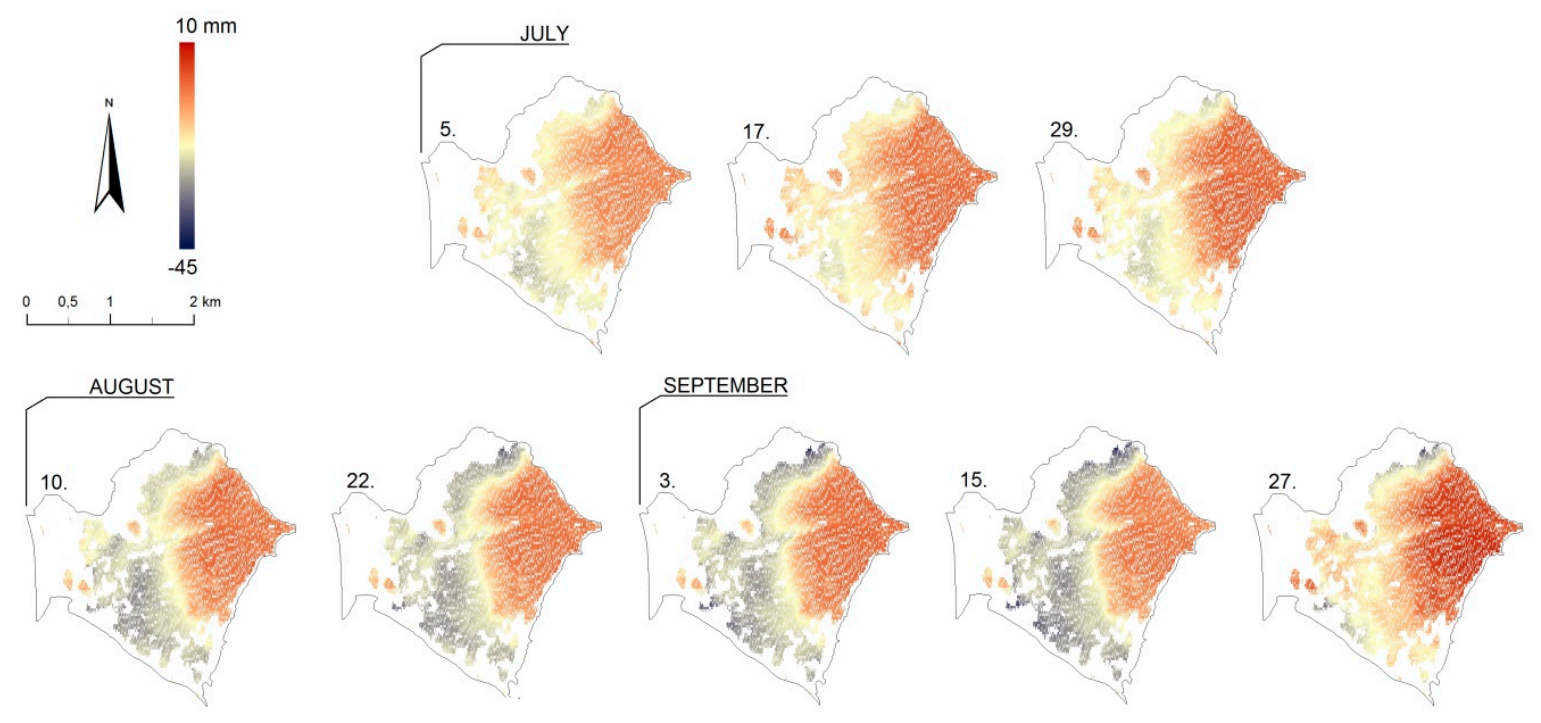

Figure 10. Vertical displacements of terrain surface indicated in Line of Sight Small Baseline Subset (LOS SBAS) analysis.

The older microfans (C-E) have the greatest range and reach the shore. They document the lateral migration of the main Kvisla channel and the lateral expansion of the sandur. The range of the younger fans (A-B) is shorter by approximately $50 \%$, which can be accounted for by the decreasing energy of the runoff and by limited bed load transport. The analysis presented here also documents the evolution of the outwash fan at the estuary of the Werenskioldelva, in the Nottingham bay. The area rapidly developed in the 1970s. The available materials did not allow, however, the identification of the complete sediment growth in the underwater part of the bay [79].

Dating of the fossil tundra found in the layer deformed by the push moraine under the pressure of the forming Werenskiold Glacier end moraine contradicts Baranowski and Karlén's [43] conclusions about the earlier Holocene advance of the Werenskiold Glacier but is consistent with other reconstructions of landscape evolution for this area [80]. Limiting the age of push moraines to the period of 770-520 BP relates the glacier advance (surge?) and forming of the end moraine, which deformed the ground, to the LIA. Paleoclimatic reconstructions demonstrate that this was the coldest period of the Holocene in Svalbard [81,82]. It limits the timeframe in which the Elveflya outwash fan evolved.

The results of electromagnetic measurements performed on the surfaces of the two outwash fans indicate that permafrost is present in the ground only in a part of the area. Low electrical resistivities measured in the distal part of the Elveflya fan and in the Nottingham bay exclude the possibility of ground ice in this zone. The presence of permafrost is suggested, however, by high electrical resistivity values in the proximal part of the Elveflya fan. Such an interpretation is consistent with studies on electromagnetic measurements conducted in areas of permafrost [45]. Resistivity inversion models do not show any substantial changes related to the varied geology of the area. Decreasing electrical resistivity from the terrain surface of the proximal zone correlates with the existence of an active layer of permafrost. However, modeling based on measurement points at three depth levels $(2.2,4.2$, and 6.7 $\mathrm{m}$ ) does not provide results for unambiguous determination of its exact thickness.

The authors suggest that the clearly contrasting geoelectric properties of the ground in the proximal and distal parts of the Elveflya fan should be related to the presence or the lack of presence of ground ice depending on the variable mineralization of ground waters. In the area, the underground 
freshwater runoff from the Werenskiold Glacier catchment area meets the saline/brackish water from the Greenland Sea.

The ice core in the Werenskiold end moraine causes the main path for underground waters in shallow water-bearing layers to be still in the channel zone of the Kvisla river. Although direct measurements of ground water mineralization in this zone were not performed during the field studies, the parameter may be provided on the basis of hydrogeological measurements previously performed in this location. The mineralization of water flowing from the springs located in front of the Werenskiold Glacier typically does not exceed $75 \mathrm{mg} \mathrm{L}^{-1}$. Only during periods of intensive thawing processes on the surface of the glacier may it exceed $200 \mathrm{mg} \mathrm{L}^{-1}[83,84]$. Similar mineralization levels of the runoff water flowing in the Werenskiold river from the Werenskiold Glacier catchment area were identified during long-term studies on the chemical denudation in this area [85].

The mineralization of sea water is several times higher. In the bays of the Greenland Sea, in the Hornsund area, at depths greater than $50 \mathrm{~m}$, the mineralization is 34.7\%-34.9\% [86,87]. In more shallow layers, it can be reduced by river mouths $[88,89]$. At the bottom of the Skoddebukta (bay), which neighbors the study area, the measured salinity was 33.5-34.5 PSU, and temperatures ranged from -0.46 to $-0.74{ }^{\circ} \mathrm{C}$ ([90] after [91]). The thermal currents of the near-surface sea waters are more varied. Typically, in the winter, the water temperature decreases to approximately $-2{ }^{\circ} \mathrm{C}$, and in the summer it warms to +3 to $+6^{\circ} \mathrm{C}$ [87].

Intrusion of sea water inland is a normal phenomenon observed in shores worldwide [92-97]. In the case of the Svalbard shore, the influence of the saline and relatively warm sea water on the permafrost in the land zone has not been, until recently, given adequate attention, and the existing schemes of groundwater circulation have not concentrated on the coastal zone $[98,99]$. The phenomenon of sea water intrusion inland has been illustrated in the Hornsund region with the use of electrical resistivity tomography $[6,7]$.

Unfortunately, the results of the study do not allow clear conclusions on the ground temperatures in the distal area of the Elveflya fan. The ground may be both unfrozen (with the temperature $>0$ ${ }^{\circ} \mathrm{C}$ ), and be in a cryotic state (at temperature $\leq 0{ }^{\circ} \mathrm{C}$ ), as is the case in marine cryopegs observed in the Arctic [100]. Based on Gregersen et al. [101], it can be concluded that salty soils remain unfrozen even at -2 to $-3{ }^{\circ} \mathrm{C}$. During the investigations of the phase composition of the water and structural properties of saline soils, Tsytovich et al. [102] noticed a shift of the phase transition from about -0.4 to $-1.6^{\circ} \mathrm{C}$ (frozen) and -0.6 to $-3.5^{\circ} \mathrm{C}$ (thawed) for soils with low salinity and from 1.2 to $-21.8^{\circ} \mathrm{C}$ (frozen) and -4.9 to $-41.0^{\circ} \mathrm{C}$ (thawed) for soils with high salinity. Conclusive evidence would require direct measurements of the ground temperatures in boreholes.

Interpretation of the results of electromagnetic measurements in the proximal part of the Elveflya fan may be more definite. The obtained ground resistivity values $(\rho \geq 1 \mathrm{k} \Omega . \mathrm{m})$ are typical of cryotic ground formations [103-109]. Except the near-surface layer, high resistivities occur in the complete vertical profile, without major differences resulting from the texture and structure of sediments or the vicinity of the bedrock. Therefore, the decisive factor for the resistivity values seems to be the presence of ground ice. Its presence may be caused by fresh groundwaters percolating into this zone from the side of the Werenskiold Glacier.

The analysis of the SBAS-based time models seems to confirm this interpretation. In the proximal part of the Elveflya fan, vertical ground movement during the arctic summer is insignificant, which may be due to permafrost inside the ground (except its top active layer), stabilizing the fan sediments. In the distal part of the fan, the vertical movements are several times greater. With no stabilization from the ground ice, the surface responds more strongly to humidity changes, lowering when the soil is dry and expanding when the soil is wet and freezes in the fall (Figure 11). The morphological effect of these processes includes cracks extending parallel to the seashore. 


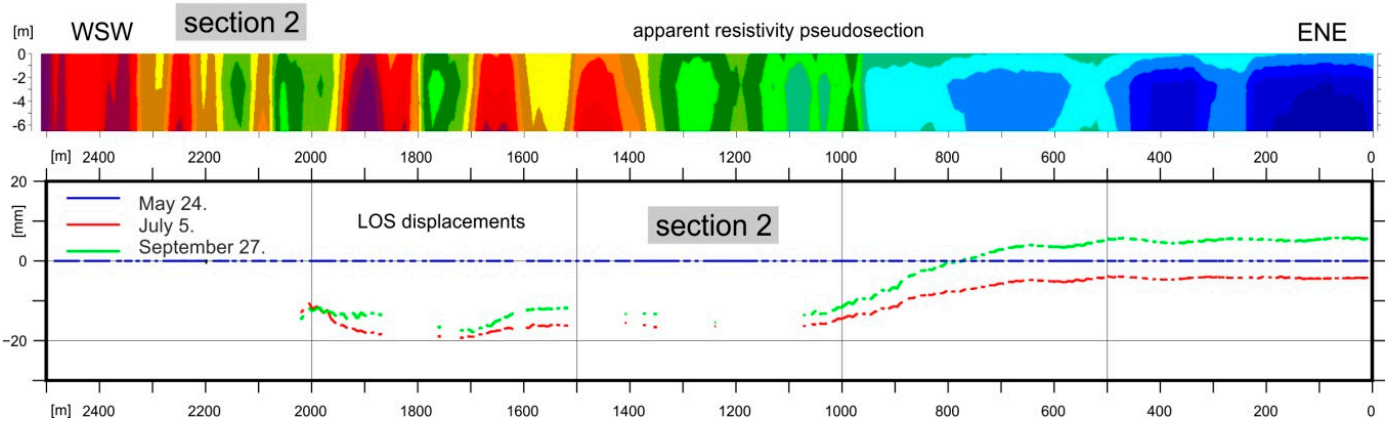

Figure 11. Comparison of the ground electrical resistivity and vertical displacements of the terrain surface (LOS SBAS). The May 24 is the reference point for LOS SBAS analysis.

Due to the lack of direct observations of the structural features of the sediments forming the Elveflya outwash fan, it cannot be unambiguously determined how they affect the observed subsidence and heave processes. It can be assumed that the presence of fine-grained sediments in the distal part of the outwash fan is another reason for greater surface dynamics in contrast to the coarse-grained sediments in the fan apex.

The seasonal movements of the ground surface in the form of subsidence and heave correspond to patterns documented in studies based on field measurements (e.g., [110,111]). The elevation changes are the response of the soil to atmospheric forcing. Interferometric Synthetic Aperture Radar (InSAR) studies conducted for the area around Longyearbyen in Svalbard [31] indicate similar values of vertical ground displacements as calculated in the presented analysis. The magnitude of $2 \mathrm{D}$ vectors in multi-year stacking for pre-recent alluvial sediments around Longyearbyen was specified on 13-25 mm (maximum 80 ) per summer.

\section{Conclusions}

Based on the obtained results and on the above discussion, the authors propose several basic conclusions. These will be provided in the points below:

1. The analysis of the existing age determination data for organic deposits and the datings of fossil tundra identified in the glacio-tectonic deformed layer in front of the Werenskiold Glacier end moraine has shown that the advance of the glacier and the evolution of the outwash fans in its marginal zone can be dated to the Little Ice Age. The breakthrough date in the evolution of the investigated sandurs is the years 1963-1969, when the water flow in the Kvisla river ceased as a result of hydrographic changes and the capturing of the river by the Breelva river. The new river, named Werenskioldelva, directed all of the transported bed load towards the Nottingham bay. The Elveflya fan was no longer built-up with fluvio-glacial sediments.

2. The photointerpretation allowed the identification of six separate parts in the Elveflya sandur and of their evolution stages. Lateral migration of the Kvisla channels, which is clearly manifested in the separate microfans, could be the result of extreme water discharges. The range of the two youngest microfans is approximately $50 \%$ shorter than that of the three older microfans, which may be due to the change in the quantity of the bed load transported outside of the end moraine by the Kvisla river. The sixth microfan is not related to the activity of the Kvisla river, and instead may be attributed to the sediment slopewash at the Werenskiold Glacier end moraine.

3. The Nottingham outwash fan, whose evolution rate has increased since the 1970s, grows at an average rate of $13,400 \mathrm{~m}^{2} \cdot \mathrm{year}^{-1}$. Its surface growth rate has increased from $5700 \mathrm{~m}^{2} \cdot$ year $^{-1}$ in the period of $1985-2000$ to $24,900 \mathrm{~m}^{2} \cdot \mathrm{year}^{-1}$ over the years $2010-2017$. This means an approximately fivefold increase of the fan aggradation rate.

4. High electrical resistivity values observed under the proximal part of the Elveflya fan should be interpreted as evidence of permafrost. Low electrical resistivities measured in the distal part of 
the outwash fan exclude the possibility of ground ice in this zone. Permafrost is either not present in the area or the ground is in a cryotic condition (marine cryopeg), but conclusive evidence cannot be provided without direct borehole measurements of the ground temperatures.

5. In the absence of terrain and geological conditions, the reason behind the varied conditions stimulating ground ice development seems to lie in the hydrogeology of the area: An underground inflow of fresh groundwater from the side of the Werenskiold Glacier to the proximal part of the Elveflya fan and the intrusion of saline sea water in the ground of the distal part of the fan.

6. The SBAS analysis of LOS displacement indicates that the surface of Elveflya is relatively stable in the proximal part (apex) of the fan and under the end moraine of the Werenskiold Glacier. Displacements (subsidence, heave) of up to $5 \mathrm{~cm}$ are observed in the distal part (toe) of the fan. This division overlaps precisely with the zones of high/low ground resistivity values. This relationship allows a conclusion that the displacements are due to permafrost. The ground with ice presence shows greater stability. The zone subjected to the intrusion of sea water deforms more, as it dries in the summer and is thus prone to contractions, while freezing of the wet ground in the fall causes its heave. These movements result in cracks, which extend in the ground parallel to the seashore and which are observed only in the distal part of the Elveflya fan.

Author Contributions: Conceptualization, M.K.; methodology, M.K., M.Ł., T.G., W.M.; software, M.K., M.Ł., T.G., W.M.; validation, M.K., M.Ł., T.G., W.M.; formal analysis, M.K., M.Ł., T.G., W.M.; investigation, M.K., M.Ł.; resources, M.K., M.Ł., T.G., W.M.; data curation, M.K., M.Ł., T.G., W.M.; writing-M.K., M.Ł., T.G., W.M., writing—review and editing, M.K.; visualization, M.K., M.Ł., T.G., W.M.; supervision, M.K.; project administration, M.K.; funding acquisition, M.K., T.G. All authors have read and agreed to the published version of the manuscript.

Funding: This research has been financially supported in research project no. 2015/19/D/ST10/02869 of the National Science Centre, Poland (for M.K. and M.Ł.) and by statutory funds available in the Faculty of Geoengineering, Mining and Geology, Wrocław University of Science and Technology no. 049U/0098/19 (for T.G. and W.M.).

Acknowledgments: Used aerial photographs of the Norwegian Polar Institute were purchased as part of the order ZP. 2420.1.IGRR.ZG.2013 (2013-01-9) financed from statutory funds of the Institute of Geography and Regional Development, University of Wroclaw.

Conflicts of Interest: The authors declare no conflict of interest. The funders had no role in the design of the study; in the collection, analyses, or interpretation of data; in the writing of the manuscript, or in the decision to publish the results.

\section{Appendix A Evolution of Near-Shore Outwash Fans and Permafrost Spreading Under Their Surface: A Case Study from Svalbard}

Table A1. Interferometric Synthetic Aperture Radar (InSAR) processing methods and parameters.

\begin{tabular}{cccccc}
\hline $\begin{array}{c}\text { Dataset/Orbit } \\
\text { Path/Track } \\
\text { Number }\end{array}$ & $\begin{array}{c}\text { InSAR } \\
\text { Processing } \\
\text { Method }\end{array}$ & $\begin{array}{c}\text { Spatial Resolution Range } \\
\times \text { Azimuth/Pixel Spacing } \\
\text { Range } \times \text { Azimuth }\end{array}$ & $\begin{array}{c}\text { Maximum Spatial } \\
\text { and Temporal } \\
\text { Baselines }\end{array}$ & $\begin{array}{c}\text { Number of } \\
\text { Selected } \\
\text { Interferograms }\end{array}$ & $\begin{array}{c}\text { Coherence } \\
\text { Filter }\end{array}$ \\
\hline $\begin{array}{c}\text { S1A/1B IWS } \\
\text { Ascending } \\
14\end{array}$ & $\begin{array}{c}\text { Small Baseline } \\
\text { Subset (SBAS) } \\
2018\end{array}$ & $\begin{array}{c}2.7-3.5 / 22.5-22.7 \mathrm{~m} \\
2.3 \times 14.1 \mathrm{~m}\end{array}$ & $\begin{array}{c}118 \mathrm{~m} \\
42 \mathrm{~d}\end{array}$ & 84 & $\begin{array}{c}0.6 \mathrm{in}>50 \% \\
\text { interferograms }\end{array}$ \\
\hline $\begin{array}{c}\text { S1A/1B IWS } \\
\text { Descending }\end{array}$ & $\begin{array}{c}\text { Small Baseline } \\
\text { Subset (SBAS) } \\
154\end{array}$ & $\begin{array}{c}2.7-3.5 / 22.5-22.7-\mathrm{m} \\
2018\end{array}$ & $2.3 \times 14.1 \mathrm{~m}$ & $132 \mathrm{~m}$ & 101 \\
$42 \mathrm{~d}$ & 0.5 in $>50 \%$ \\
interferograms
\end{tabular}




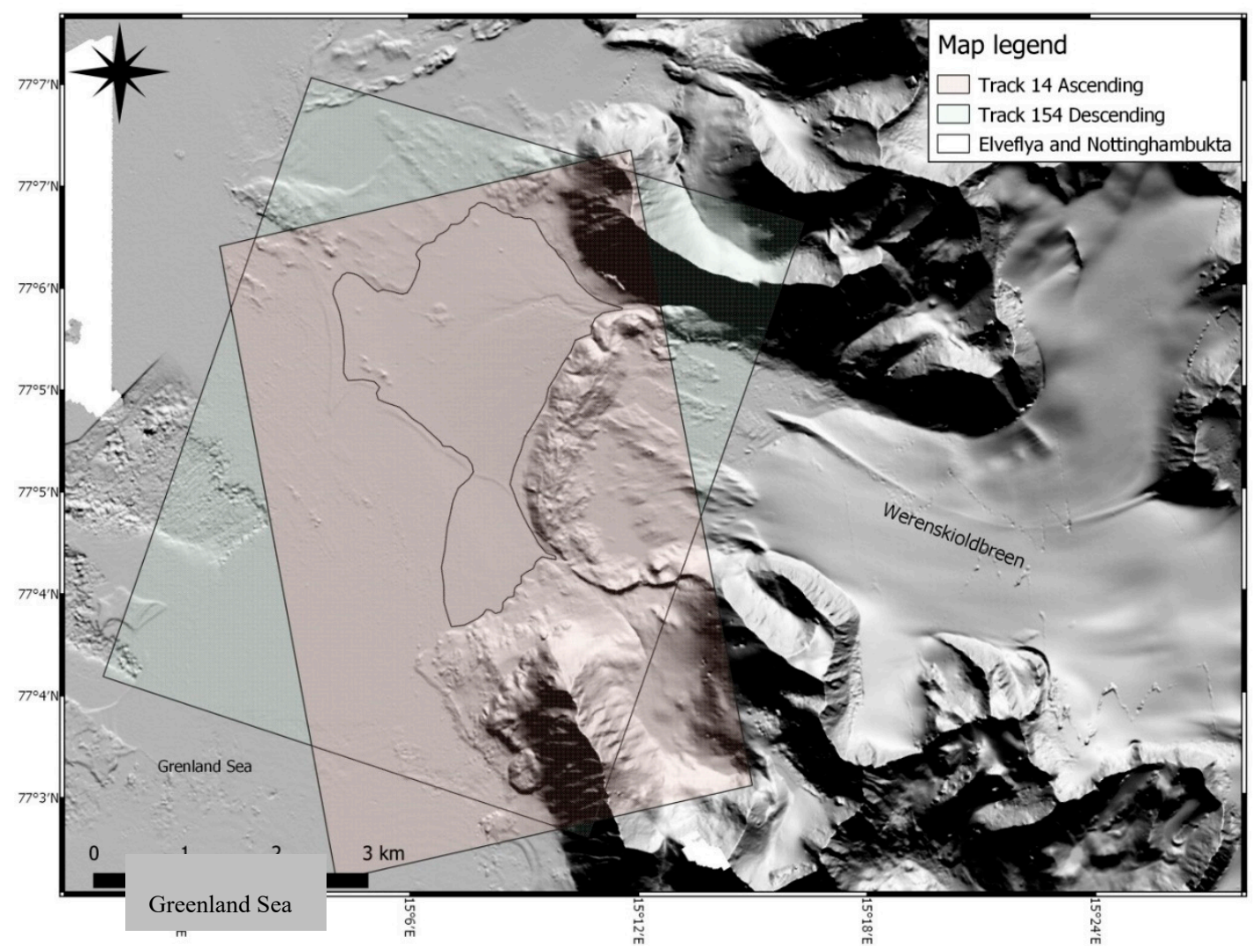

Figure A1. Extent of the processed area of Sentinel 1A/1B Tracks 14 (ascending) and 154 (descending). Only the SAR range used to calculate the LOS displacements is shown in the figure. In background Digital Elevation Model (DEM) from ArcticDEM https://www.pgc.umn.edu/data/arcticdem/.

(a)

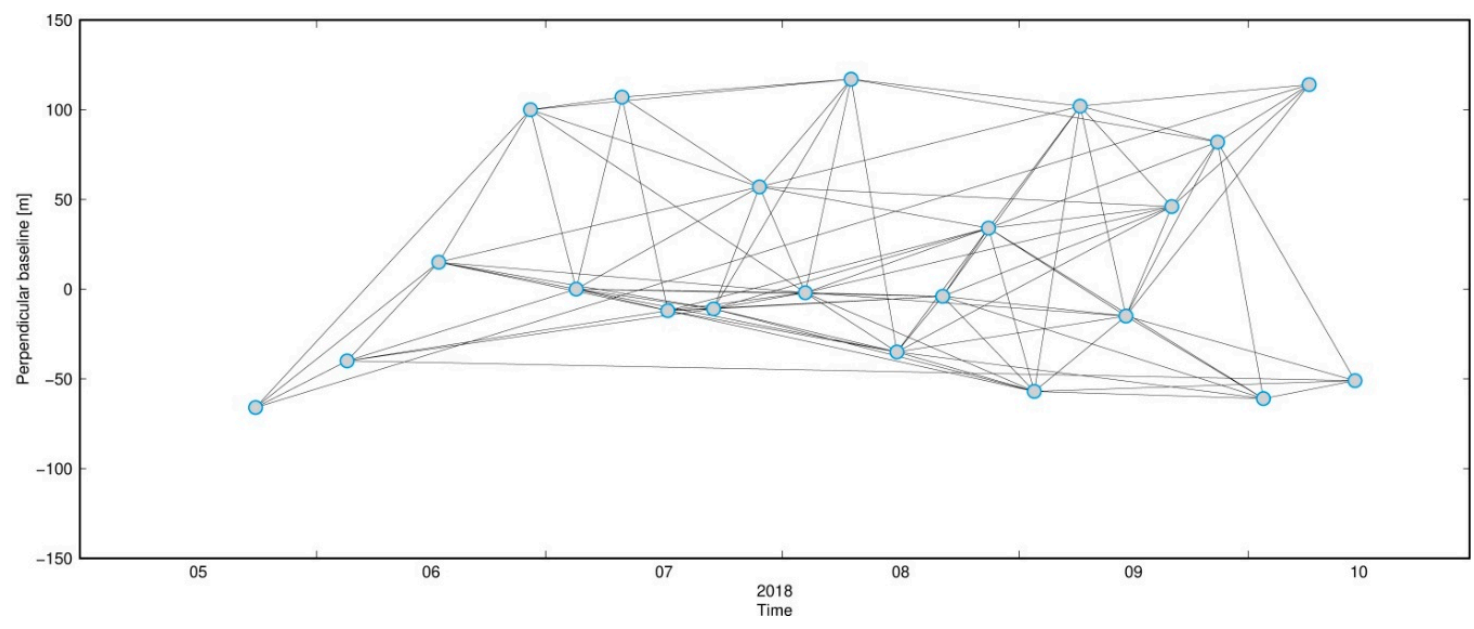

Figure A2. Cont. 
(b)

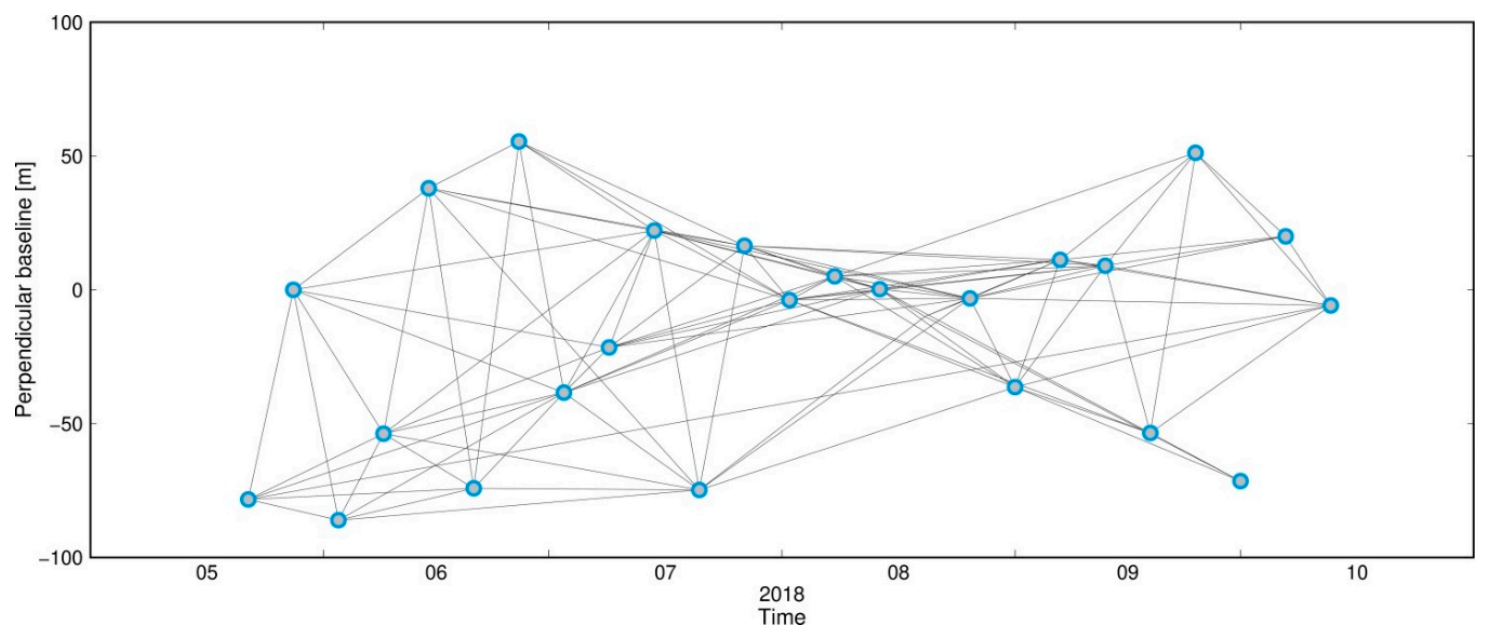

Figure A2. Baseline for tracks (a) 14 and (b) 154. Baselines used to calculate Line of Sight (LOS) displacements in each time period.

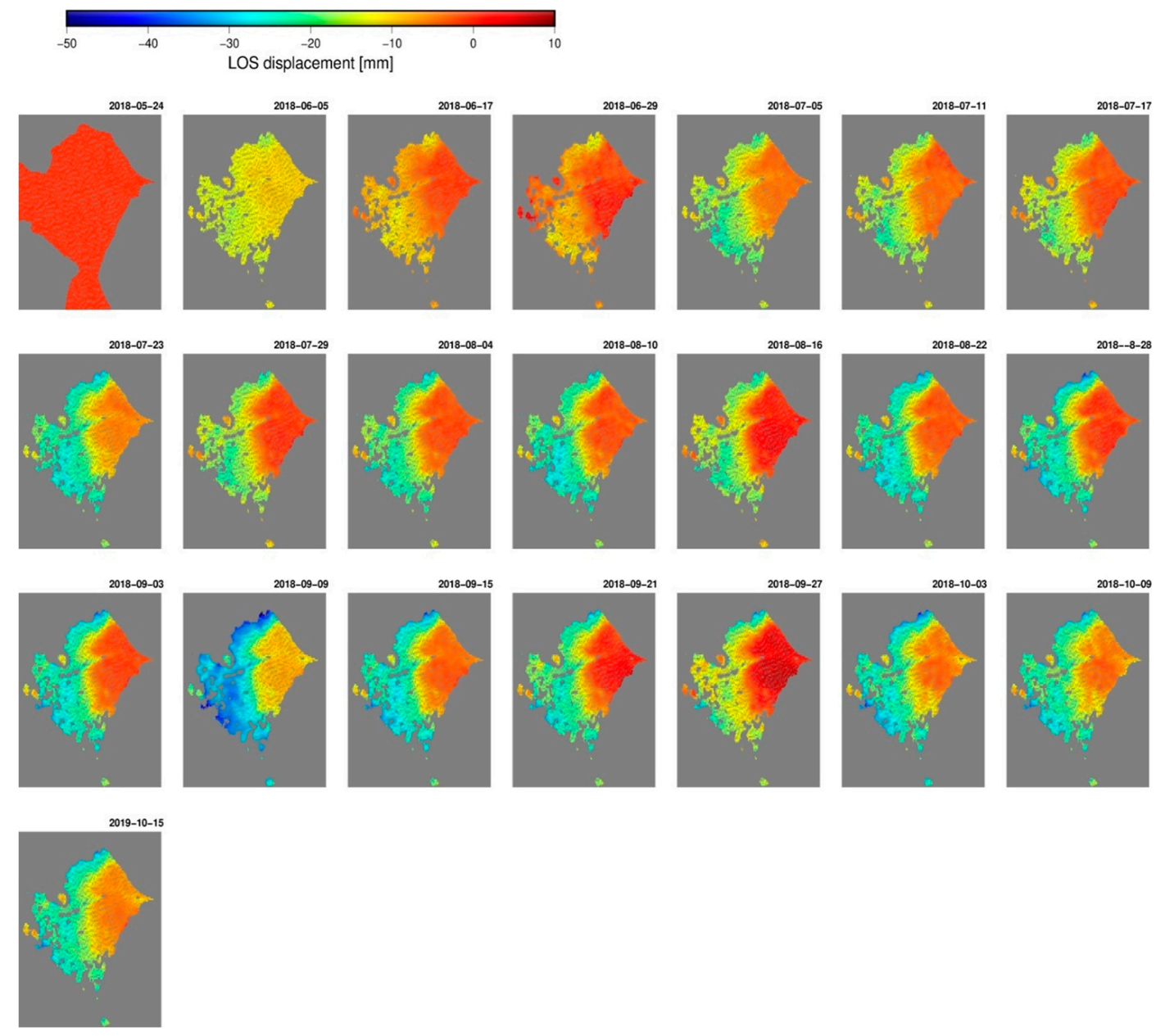

Figure A3. Time series for track 14 for the Elveflya outwash fan. All LOS displacements in each of the time periods. The reference time period is 24 May. 


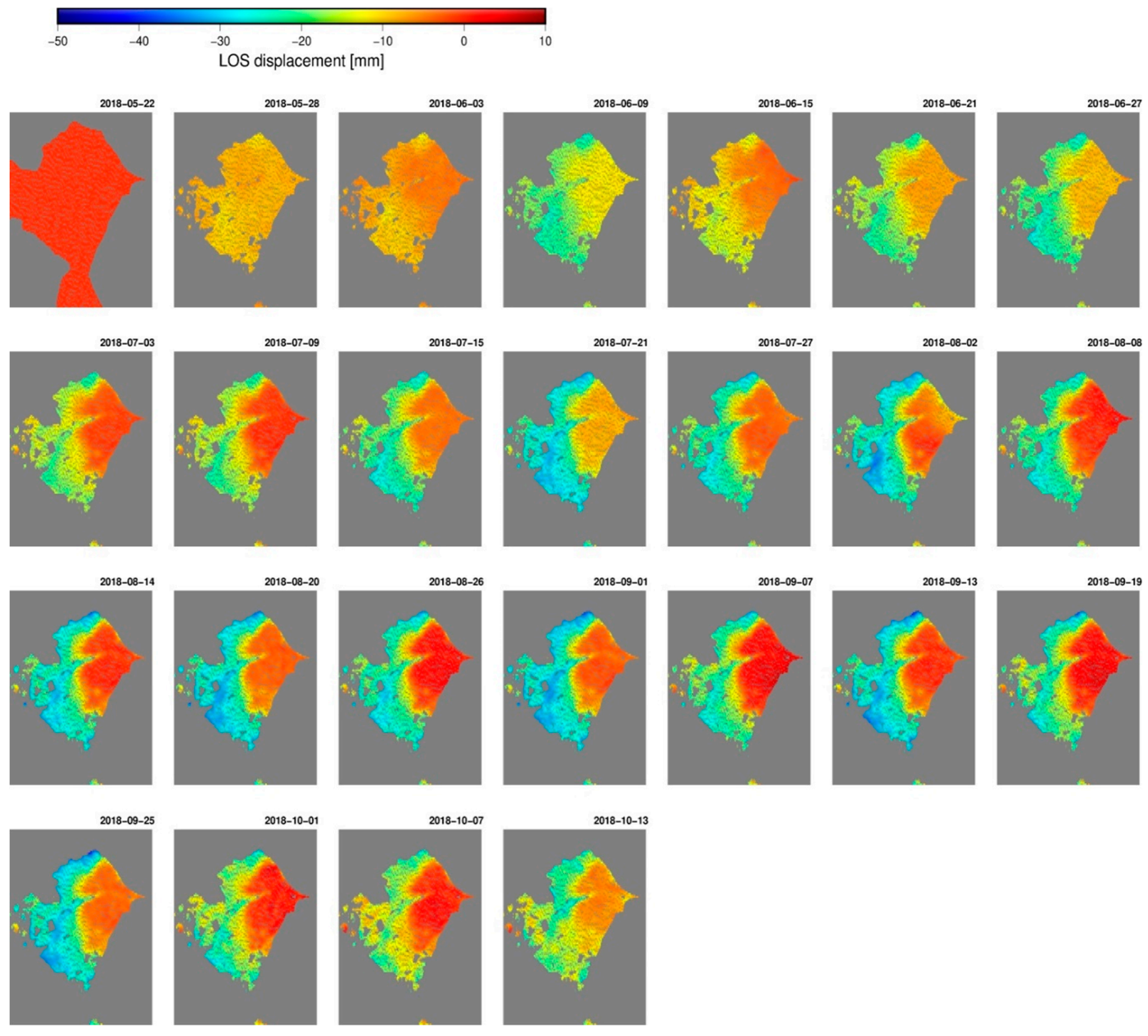

Figure A4. Time series for track 154. All LOS displacements in each of the time periods. The reference time period is 22 May.
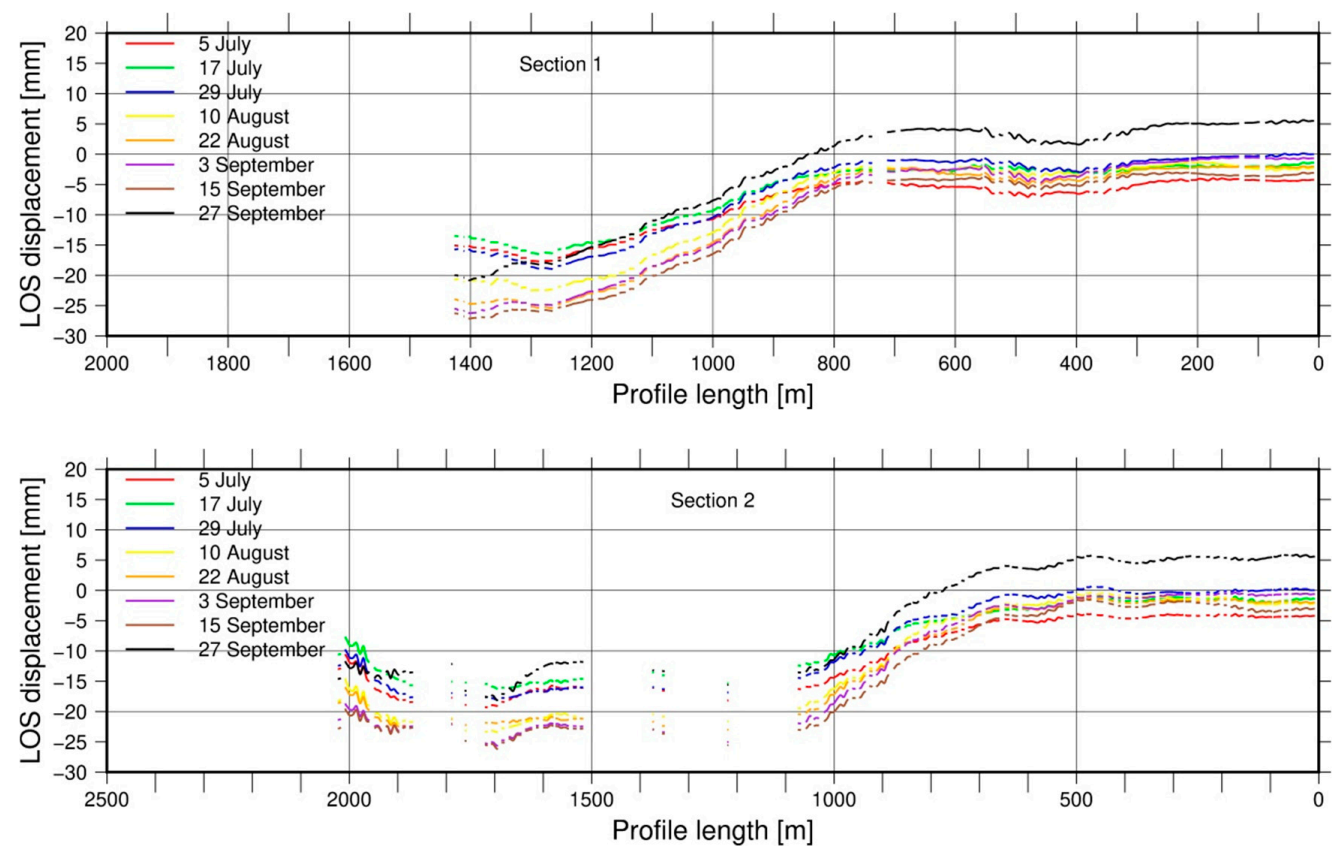

Figure A5. Cont. 

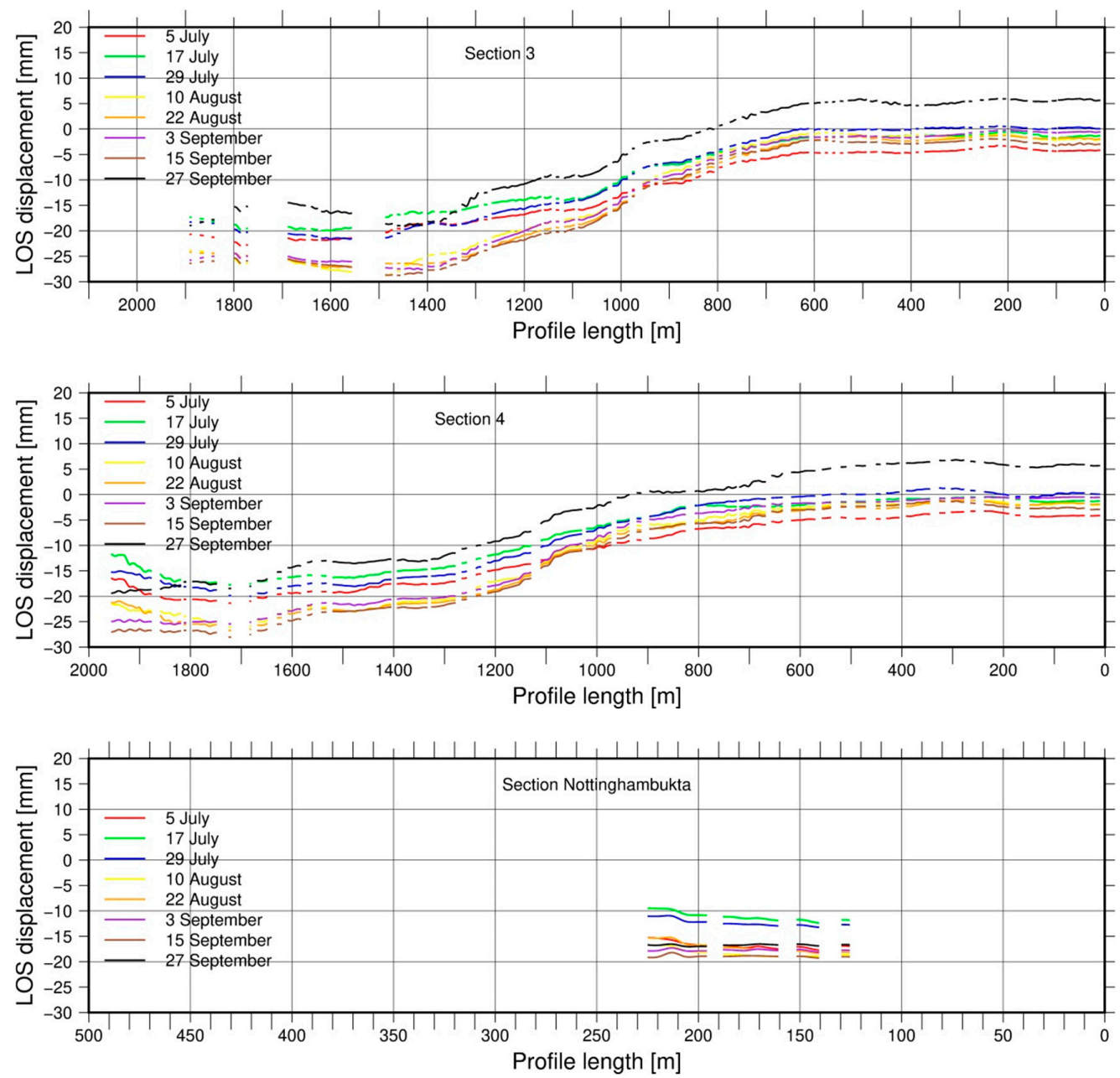

Figure A5. Cross-Sections 1-4 and the Nottingham fan corresponds to electromagnetic measurements in eight time periods.

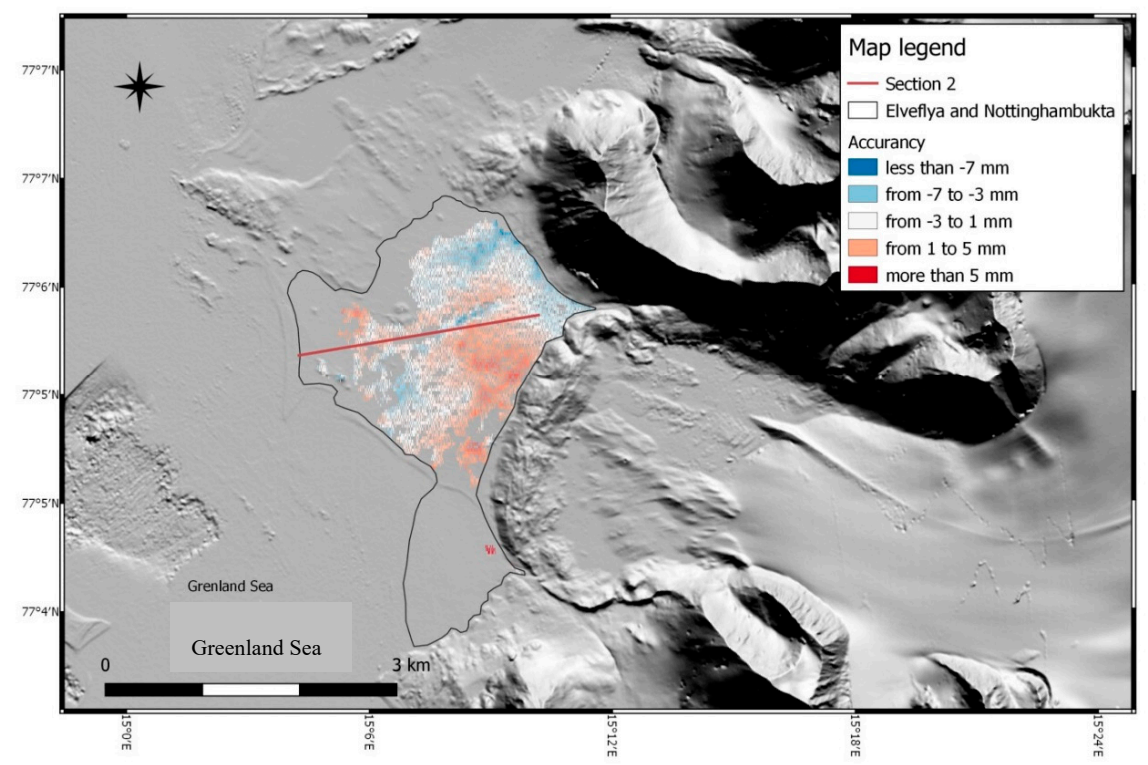

Figure A6. Accuracy of thee displacement determination on the entire surface of the elaboration. In the background, the Elveflya and Nottingham fans range and DEM from ArcticDEM https://www.pgc. umn.edu/data/arcticdem/. 


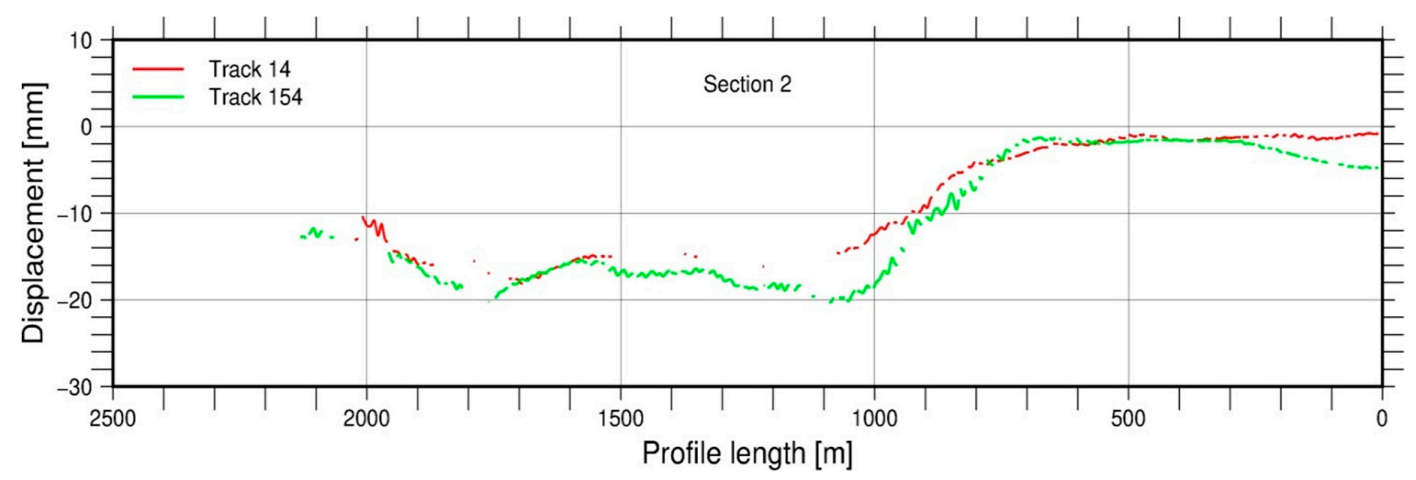

Figure A7. Accuracy of displacement. Compilation of two tracks in comparable time (2 and 4 July) Section 2 is an example.

\section{References}

1. Isaksen, K.; Mühll, D.V.; Gubler, H.; Kohl, T.; Sollid, J.L. Ground surface-temperature reconstruction based on data from a deep borehole in permafrost at Janssonhaugen, Svalbard. Ann. Glaciol. 2000, 31, 287-294. [CrossRef]

2. Christiansen, H.H.; Etzelmüller, B.; Isaksen, K.; Juliussen, H.; Farbrot, H.; Humlum, O.; Johansson, M.; Ingeman-Nielsen, T.; Kristensen, L.; Hjort, J.; et al. The thermal state of permafrost in the Nordic area during the international polar year 2007-2009. Permafr. Periglac. Process. 2010, 21, 156-181. [CrossRef]

3. Haeberli, W. Investigating glacier-permafrost relationships in high-mountain areas: Historical background, selected examples and research needs. In Cryospheric Systems: Glaciers and Permafrost; Harris, C., Murton, J.B., Eds.; Special Publications; Geological Society: London, UK, 2005; Volume 242, pp. 29-37.

4. Harris, C.; Murton, J.B. Interactions between Glaciers and Permafrost: An Introduction. Cryospheric Systems: Glaciers and Permafrost; Special Publications; Geological Society: London, UK, 2005; Volume 242, pp. 1-9.

5. Waller, R.I.; Murton, J.B.; Kristensen, L. Glacier-permafrost interactions: Processes, products and glaciological implications. Sediment. Geol. 2012, 255-256, 1-28. [CrossRef]

6. Kasprzak, M.; Strzelecki, M.C.; Traczyk, A.; Kondracka, M.; Lim, M.; Migała, K. On the potential for a bottom active layer below coastal permafrost: The impact of seawater on permafrost degradation imaged by electrical resistivity tomography (Hornsund, SW Spitsbergen). Geomorphology 2017, 293 Pt B, 347-359. [CrossRef]

7. Strzelecki, M.; Kasprzak, M.; Lim, M.; Świrad, Z.M.; Jaskólski, M.; Pawłowski, Ł.; Modzel, P. Cryo-conditioned rocky coast systems: A case study from Wilczekodden, Svalbard. Sci. Total Environ. 2017, 607-608, 443-453. [CrossRef] [PubMed]

8. Angelopoulos, M.; Westermann, S.; Overduin, P.P.; Faguet, A.; Olenchenko, V.; Grosse, G.; Grigoriev, M.N. Heat and salt flow in subsea permafrost modeled withCryoGRID2. J. Geophys. Res. Earth Surf. 2019, 124, 920-937. [CrossRef] [PubMed]

9. Nuth, C.; Kohler, J.; König, M.; von Deschwanden, A.; Hagen, O.; Kääb, A.; Moholdt, G.; Pettersson, R. Decadal changes from a multi-temporal glacier inventory of Svalbard. Cryosphere 2013, 7, 1603-1621. [CrossRef]

10. Małecki, J. Accelerating retreat and high-elevation thinning of glaciers in central Spitsbergen. Cryosphere 2016, 10, 1317-1329. [CrossRef]

11. Bourriquen, M.; Mercier, D.; Baltzer, A.; Fournier, J.; Costa, S.; Roussel, E. Paraglacial coasts responses to glacier retreat and associatedshifts in river floodplains over decadal timescales (1966-2016), Kongsfjorden, Svalbard. Land Degrad. Dev. 2018, 29, 4173-4185. [CrossRef]

12. Strzelecki, M.C.; Long, A.J.; Lloyd, J.M.; Małecki, J.; Zagórski, P.; Pawłowski, Ł.; Jaskólski, M.W. The role of rapid glacier retreat and landscape transformation in controlling the post-Little Ice Age evolution of paraglacial coasts in central Spitsbergen (Billefjorden, Svalbard). Land Degrad. Dev. 2018, 29, 1962-1978. [CrossRef] 
13. Tomczyk, A.M.; Ewertowski, M.W.; Stawska, M.; Rachlewicz, G. Detailed alluvial fan geomorphology in a high-arctic periglacial environment, Svalbard: Application of unmanned aerial vehicle (UAV) surveys. J. Maps 2019, 15, 460-473. [CrossRef]

14. Forman, S.L.; Lubinski, D.J.; Ingólfsson, Ó.; Zeeberg, J.J.; Snyder, J.A.; Siegert, M.J.; Matishov, G.G. A review of postglacial emergence on Svalbard, Franz Josef Land and Novaya Zemlya, northern Eurasia. Quat. Sci. Rev. 2004, 23, 1391-1434. [CrossRef]

15. Osterkamp, T.E. Sub-sea permafrost. In Encyclopedia of Ocean Sciences; Steele, J.H., Thorpe, S.A., Turekian, K.K., Eds.; Academic Press: San Diego, CA, USA, 2001; pp. 2902-2912.

16. Mackay, J.R. Offshore permafrost and ground ice, Southern Beaufort Sea, Canada. Can. J. Earth Sci. 1972, 9, 1550-1561. [CrossRef]

17. Hill, P.R.; Lewis, C.P.; Desmarais, S.; Kauppaymuthoo, V.; Rais, H. The Mackenzie Delta: Sedimentary processes and facies of a high-latitude, fine-grained delta. Sedimentology 2001, 48, 1047-1078. [CrossRef]

18. Romanovskii, N.N.; Hubberten, H.-W.; Gavrilov, A.V.; Tumskoy, V.E.; Kholodov, A.L. Permafrost of the east Siberian Arctic shelf and coastal lowlands. Quat. Sci. Rev. 2004, 23, 1359-1369. [CrossRef]

19. Rekant, P.; Cherkashev, G.; Vanstein, B.; Krinitsky, P. Submarine permafrost in the nearshore zone of the southwestern Kara Sea. Geo-Mar. Lett. 2005, 25, 183-189. [CrossRef]

20. Rekant, P.; Bauch, H.A.; Schwenk, T.; Portnov, A.; Gusev, E.; Spiess, V.; Cherkashov, G.; Kassens, H. Evolution of subsea permafrost landscapes in Arctic Siberia since the Late Pleistocene: A synoptic insight from acoustic data of the Laptev Sea. Arktos 2015, 1, 11. [CrossRef]

21. Overduin, P.P.; Wetterich, S.; Günther, F.; Grigoriev, M.N.; Grosse, G.; Schirrmeister, L.; Hubberten, H.-W.; Makarov, A. Coastal dynamics and submarine permafrost in shallow water of the central Laptev Sea, East Siberia. Cryosphere 2016, 10, 1449-1462. [CrossRef]

22. Humlum, O.; Instanes, A.; Sollid, J.L. Permafrost in Svalbard: A review of research history, climatic background and engineering challenges. Polar Res. 2003, 22, 191-215. [CrossRef]

23. Etzelmüller, B.; Schuler, T.V.; Isaksen, K.; Christiansen, H.H.; Farbot, H.; Benestad, R.E. Modelling past and future permafrost conditions in Svalbard. Cryosphere Discuss. 2010, 4, 1877-1908. [CrossRef]

24. Christiansen, H.H.; Gilbert, G.L.; Demidov, N.; Guglielmin, M.; Osuch, M.; Boike, J. Permafrost thermal snapshot and active-layer thickness in Svalbard 2016-2017. In SESS Report 2018-The State of Environmental Science in Svalbard; Svalbard Science Centre: Longyearbyen, Norway, 2018; 22p.

25. Noetzli, J.; Christiansen, H.H.; Deline, P.; Gugliemin, M.; Isaksen, K.; Romanovsky, V.E.; Smith, S.L.; Zhao, L.; Streletskiy, D.A. Permafrost thermal state [in "State of the Climate in 2017"]. Bull. Am. Meteorol. Soc. 2018, 99, 20-22.

26. Biskaborn, B.K.; Smith, S.L.; Noetzli, J.; Matthes, H.; Vieira, G.; Streletskiy, D.A.; Schoeneich, P.; Romanovsky, V.E.; Lewkowicz, A.G.; Abramov, A.; et al. Permafrost is warming at a global scale. Nat. Commun. 2019, 10, 264. [CrossRef] [PubMed]

27. Kasprzak, M.; Szymanowski, M. Terrain determinants of permafrost active layer thermal conditions: A case study from Arctic deglaciated catchment (Bratteggdalen, SW Spitsbergen). Peer J. Prepr. 2018, 6, e27119v2. [CrossRef]

28. Berardino, P.; Fornaro, G.; Lanari, R.; Sansosti, E. A new algorithm for surface deformation monitoring based on small baseline differential SAR interferograms. IEEE Trans. Geosci. Remote Sens. 2002, 40, 2375-2383. [CrossRef]

29. Zhao, R.; Li, Z.W.; Feng, G.C.; Wang, Q.J.; Hu, J. Monitoring surface deformation over permafrost with an improved SBAS-InSAR algorithm: With emphasis on climatic factors modeling. Remote Sens. Environ. 2016, 184, 276-287. [CrossRef]

30. Eckerstorfer, M.; Eriksen, H.Ø.; Rouyet, L.; Christiansen, H.H.; Lauknes, T.R.; Blikra, L.H. Comparison of geomorphological field- and 2D InSAR mapping of periglacial landscape activity at Nordnesfjellet, Northern Norway: Comparison of geomorphological field- and 2D InSAR mapping. Earth Surf. Process. Landf. 2018, 43, 2147-2156. [CrossRef]

31. Rouyet, L.; Lauknesa, T.R.; Christiansen, H.H.; Strand, S.M.; Larsen, Y. Seasonal dynamics of a permafrost landscape, Adventdalen, Svalbard, investigated by InSAR. Remote Sens. Environ. 2019, 231. [CrossRef]

32. Church, M. Baffin Island Sandurs: A study of arctic fluvial processes. Geol. Survey Canada Bull. 1972, 216, 208. 
33. Maizels, J. Lithofacies variations within sandur deposits: The role of runoff regime, flow dynamics and sediment supply characteristics. Sediment. Geol. 1993, 85, 299-325. [CrossRef]

34. Marren, P. Glacier margin fluctuations, Skaftafellsjökull, Iceland: Implications for sandur evolution. Boreas 2002, 31, 75-81. [CrossRef]

35. Marren, P.M.; Russel, A.J.; Rushmer, E.L. Sedimentology of a sandur formed by multiple jökulhlaups, Kverkfjöll, Iceland. Sediment. Geol. 2009, 213, 77-88. [CrossRef]

36. Weckwerth, P.; Greń, K.; Sobota, I. Controls on downstream variation in surficial sediment size of an outwash braidplain developed under high Arctic conditions (Kaffiøyra, Svalbard). Sediment. Geol. 2019, 387, 75-86. [CrossRef]

37. Kolondra, L. Werenskioldbreen and Surrounding Areas. Spitsbergen, Svalbard, Norway. Orthophotomap 1:25:000; Jania, J., Kolondra, L., Aas, H.F., Eds.; Wydział Nauk o Ziemi, Uniwersytet Śląski, Sosnowiec and Norsk Polar Institutt: Tromsø, Norway, 2002.

38. Irwin, B.J.; Ventura, S.J.; Slater, B.K. Fuzzy and isodata classification of landform elements from digital terrain data in Pleasant Valley, Wisconsin. Geoderma 1997, 77, 137-154.

39. Adam, S.; Vitse, I.; Johannsen, C.; Monbaliu, J. Sediment type unsupervised classification of the Molenplaat, Westerschelde Estuary, The Netherlands. EARSeL eProc. 2006, 5, 146-160.

40. Rozenstein, O.; Karnieli, A. Comparison of methods for land-use classification incorporating remote sensing and GIS inputs. Appl. Geogr. 2011, 31, 533-544. [CrossRef]

41. Raynolds, M.K.; Walker, D.A.; Maier, H.A. NDVI patterns and phytomass distribution in the circumpolar Arctic. Remote Sens. Environ. 2006, 102, 271-281. [CrossRef]

42. Rouse, J.; Haas, R.; Scheel, J.; Deering, D. Monitoring Vegetation Systems in the Great Plains with ERTS. In Proceedings of the 3rd Earth Resource Technology Satellite (ERTS) Symposium (1), Washington, DC, USA, 10-14 December 1973; pp. 48-62.

43. Baranowski, S.; Karlén, W. Remnants of Viking Age Tundra in Spitsbergen and Northern Scandinavia. Geogr. Ann. Ser. A Phys. Geogr. 1976, 58, 35-40. [CrossRef]

44. Traczyk, A. Significnce of the Quaternary glaciatons on the relief evolution of the western coastal zone of the Spitsbergen on example of the Hornsund area (in Polish with Eng. abs.). In Środowisko Przyrodnicze Obszarów Polarnych; Kolwalska, A., Latocha, A., Marszałek, H., Pereyma, J., Eds.; Wydział Nauk Przyrodniczych Uniwersytetu Wrocławskiego, Uniwersytet Wrocławski: Wrocław, Poland, 2008; pp. 79-88, GAJT Publ.

45. Dafflon, B.; Hubbard, S.S.; Ulrich, C.; Peterson, J.E. Electrical Conductivity Imaging of Active Layer and Permafrost in an Arctic Ecosystem, through Advanced Inversion of Electromagnetic Induction Data. Vadose Zone J. 2013. [CrossRef]

46. Reynolds, J.M. Electrical Resistivity Methods. In An Introduction to Applied and Environmental Geophysics, 2nd ed.; Wiley: Chichester, UK, 2011; pp. 289-372.

47. Hauck, C. Frozen ground monitoring using DC resistivity tomography. Geophys. Res. Lett. 2002, $29,2016$. [CrossRef]

48. Ishikawa, M. Application of DC resistivity imaging to frozen ground investigations. J. Jpn. Soc. Snow Ice 2004, 66, 177-186. [CrossRef]

49. Hayley, K.; Bentley, L.R.; Gharibi, M.; Nightingale, M. Low temperature dependence of electrical resistivity: Implications for near surface geophysical monitoring. Geophys. Res. Lett. 2007, 34, L18402. [CrossRef]

50. MacKay, D.K. Electrical resistivity measurements in frozen ground, Mackenzie Delta area, Northwest Territories. Actes du Colloque de Becarest Repr. Ser. 1969, 82, 363-375.

51. Doolittle, J.A.; Brevik, E.C. The use of electromagnetic induction techniques in soils studies. Geoderma 2014, 223-225, 33-45. [CrossRef]

52. Balkov, E.V.; Fadeev, D.I.; Karin, Y.G.; Manshtein, A.K.; Manshtein, Y.A.; Panin, G.L. A new approach to shallow-depth electromagnetic sounding. Russ. Geol. Geophys. 2017, 58, 635-641. [CrossRef]

53. Loke, M.H. Manual for RES3DINV. Rapid 3-D Resistivity E IP Inversion Using the Least-Squares Method (For 3-D Surveys Using the Pole-Pole, Pole-Dipole, Dipole-Dipole, Rectangular, Wenner, Wenner-Schlumberger and non-Conventional Arrays). On Land, Aquatic and Cross-Borehole Surveys. Geoelectrical Imaging 2-D \& 3-D; Geotomo: Penang, Malaysia, 2013.

54. Sandwell, D.; Mellors, R.; Tong, X.; Wei, M.; Wessel, P. Open radar interferometry software for mapping surface deformation. Eos 2011, 92, 234. [CrossRef] 
55. Massonnet, D.; Feigl, K.L. Radar interferometry and its application to changes in the earth's surface. Rev. Geophys. 1998, 36, 441-500. [CrossRef]

56. Farr, T.; Kobrick, M. Shuttle Radar Topography Mission produces a wealth of data. Eos 2000, 81, 583-585. [CrossRef]

57. Chen, C.W.; Zebker, H.A. Phase unwrapping for large SAR interferograms: Statistical segmentation and generalized network models. IEEE Trans. Geosci. Remote Sens. 2002, 40, 1709-1719. [CrossRef]

58. Goldstein, R.M.; Werner, C.L. Radar interferogram filtering for geophysical applications. Geophys. Res. Lett. 1998, 25, 4035-4038. [CrossRef]

59. Cavalié, O.; Doin, M.P.; Lasserre, C.; Briole, P. Groundmotion measurement in the Lake Mead area, Nevada, by differential synthetic aperture radar interferometry time series analysis: Probing the lithosphere rheological structure. J. Geophys. Res. Solid Earth 2007, B3, 112. [CrossRef]

60. Lyons, S.; Sandwell, D. Fault creep along the southern San Andreas from interferometric synthetic aperture radar, permanent scatterers and stacking. J. Geophys. Res. Solid Earth 2003, 108, 1-24. [CrossRef]

61. Pereyma, J.; Migała, K.; Sikora, K. Climate. In Ancient and Modern Geosystems of Spitsbergen; Zwoliński, Z., Kostrzewski, A., Pulina, M., Eds.; Bogucki Wyd. Naukowe: Poznań, Poland, 2013; pp. 118-121.

62. Koenigk, T.; Berg, P.; Doscher, R. Arctic climate change in an ensemble of regional CORDEX simulations. Polar Res. 2015, 34, 24603. [CrossRef]

63. Osuch, M.; Wawrzyniak, T. Climate projections in the Hornsund area, Southern Spitsbergen. Pol. Polar Res. 2016, 37, 379-402. [CrossRef]

64. Przybylak, R.; Wyszyński, P. Air temperature changes in the Arctic in the period 1951-2015 in the light of observational and reanalysis data. Theor. Appl. Climatol. 2019. [CrossRef]

65. Łupikasza, E. Atmospheric precipitation. In Climate and Climate Change at Hornsund, Svalbard; Marsz, A.A., Styszyńska, A., Eds.; Gdynia Maritime Univ.: Gdynia, Poland, 2013; pp. 199-211.

66. Niedźwiedź, T.; Styszyńska, A. Snow cover at the Hornsund Station. In Climate and Climate Change at Hornsund, Svalbard; Marsz, A.A., Styszyńska, A., Eds.; Gdynia Maritime Univ.: Gdynia, Poland, 2013; pp. 367-372.

67. Ciężkowski, W.; Głowacki, T.; Grudzińska, K.K.; Kasza, D.; Zagożdżon, P. Front of the Werenskiold Glacier (Svalbard)-Changes in years 1957-2013. E3S Web Conf. 2018, 29, 1-10. [CrossRef]

68. Pulina, M.; Pereyma, J.; Kida, J.; Krawczyk, W. Characteristics of the polar hydrological year 1979/1980 in the basin of the Werenskiold Glacier, SW Spitsbergen. Pol. Polar Res. 1984, 5, 165-182.

69. 69. Marszałek, H.; Rysiukiewicz, M.; Staśko, S.; Wassik, M. Waters. In Ancient and Modern Geosystems of Spitsbergen; Zwoliński, Z., Kostrzewski, A., Pulina, M., Eds.; Bogucki Wyd. Naukowe: Poznań, Poland, 2013; pp. 125-131.

70. Majchrowska, E.; Ignatiuk, D.; Jania, J.; Marszałek, H.; Wąsik, M. Seasonal and interannual variability in runofffrom the Werenskioldbreen catchment, Spitsbergen. Pol. Polar Res. 2015, 36, 197-224. [CrossRef]

71. Czerny, J.; Kieres, A.; Manecki, M.; Rajchel, J. Geological Map of the SW Part of Wedel Jarlsberg Land, Spitsbergen 1:25 000 (with explanations); Manecki, A., Ed.; Institute of Geology and Mineral Deposits, University of Mining and Metallurgy: Cracow, Poland, 1993; pp. 1-61.

72. Baranowski, S. Thermic conditions of the periglacial tundra in SW Spitsbergen. Acta Univ. Wratislav. 1968, 68,74 .

73. Jahn, A. Soil thawing and active layer of permafrost in Spitsbergen. Acta Univ. Wratislav. 1982, 525, 57-75.

74. Grześ, M. Characteristic of permafrost active layer on the western coast of Spitsbergen (in Polish with Eng. abstract). Przeglad Geograficzny 1985, 57, 671-691.

75. Migała, K. The characteristic features of the active layer of the permafrost in the climate of Spitsbergen (in Polish with Eng. abstract). Acta Univ. Wratislav. 1994, 1590, 79-111.

76. Chmal, H.; Klementowski, J.; Migała, K. Thermal currents of active layer in Hornsund area. In Permafrost, Proceedings of the Fifth International Conference, Trondheim, Norway, 2-5 August 1988; Senneset, K., Ed.; Proceedings Volume 1; Tapir Pub.: Trondheim, Norway, 1988; pp. 44-49.

77. Migała, K.; Wojtuń, B.; Szymański, W.; Muskała, P. Soil moisture and temperature variation under different types of tundra vegetation during the growing season: A case study from the Fuglebekken catchment, SW Spitsbergen. Catena 2014, 116, 10-18. [CrossRef]

78. Kosiba, A. Glacio-hydrodynamic processes and changes on the Werenskiold Glacier and the Hans Glacier, SW-Spitsbergen. Acta Univ. Wratislav. 1982, 525, 133-152. 
79. Kowalska, A.; Sroka, W. Sedimentary environment of the Nottinghambukta delta, SW Spitsbergen. Pol. Polar Res. 2008, 29, 245-259.

80. Chmal, H. Pleistocene sea level changes and glacial history of the Hornsund area, Svalbard. Polar Res. 1987, 5, 269-270. [CrossRef]

81. Isaksson, E.; Hermanson, M.; Hicks, S.; Igarashi, M.; Kamiyama, K.; Moore, J.; Motoyama, H.; Muir, D.; Pohjola, V.; Vaikmae, R.; et al. Ice cores from Svalbard-Useful archives of past climate and pollution history. Phys. Chem. Earth. 2003, 28, 1217-1228. [CrossRef]

82. Szczuciński, W.; Zajączkowski, M.; Scholten, M. Sediment accumulation rates in subpolar fjords-Impact of post-Little Ice Age glaciers retreat, Billefjorden, Svalbard. Estuar. Coast. Shelf Sci. 2009, 85, 345-356. [CrossRef]

83. Krawczyk, W.E. Chemical characteristics of water circulating in the Werenskiold Glacier (SW Spitsbergen). In Proceedings of the 2nd International Symposium of Glacier Caves and Karst in Polar Regions, Miedzygórze-Velká Morava, Sosnowiec, Poland, 10-16 February 1992; Silesian University: Sosnowiec, Poland, 1992; pp. 65-80.

84. Olichwer, T.; Tarka, T.; Modelska, M. Chemical composition of groundwaters in the Hornsund region, southern Spitsbergen. Hydrol. Res. 2013, 44, 117-130. [CrossRef]

85. Stachnik, Ł.; Majchrowska, E.; Yde, J.C.; Nawrot, A.; Cichała-Kamrowska, K.; Ignatiuk, D.; Piechota, A. Chemical denudation and the role of sulfide oxidation at Werenskioldbreen, Svalbard. J. Hydrol. 2016, 538, 177-193. [CrossRef]

86. Zajączkowski, M.; Szczuciński, W.; Plessen, B.; Jernas, P. Benthic foraminifera in Hornsund, Svalbard: Implications for paleoenvironmental reconstructions. Polish Polar Res. 2010, 31, 349-375. [CrossRef]

87. Promińska, A.; Falck, E.; Walczowski, W. Interannual variability in hydrography and water mass distribution in Hornsund, an Arctic fjord in Svalbard. Polar Res. 2018, 37, 1495546. [CrossRef]

88. Swerpel, S. Hydrological investigations of the coastal waters in the Hornsund Fiord in the summer of 1975. Acta Univ. Wratislav. 1982, 525, 235-253.

89. Swerpel, S. The Hornsund fiord: Water masses. Pol. Polar Res. 1985, 6, 475-496.

90. Lech, J.; Walczowski, W. Data Report on Hydrological Measurements: Norwegian Sea, Fjords, Polar Front; 13.06-09.08.1994, Cruise AREX-94 (in Polish). Institute of Oceanology PAS: Sopot, Poland, 1994.

91. Włodarska-Kowalczuk, M.; Węslawski, J.M.; Kotwicki, L. Spitsbergen glacial bays macrobenthos-A comperative study. Polar Biol. 1998, 20, 66-73. [CrossRef]

92. Martínez, J.; Benavente, J.; García-Aróstegui, J.L.; Hidalgo, M.C.; Rey, J. Contribution of electrical resistivity tomography to the study of detrital aquifers affected by seawater intrusion-extrusion effects: The river Vélez delta (Vélez-Málaga, southern Spain). Eng. Geol. 2009, 108, 161-168. [CrossRef]

93. Morrow, F.J.; Ingham, M.R.; McConchie, J.A. Monitoring of tidal influences on the saline interface using resistivity traversing and cross-borehole resistivity tomography. J. Hydrol. 2010, 389, 69-77. [CrossRef]

94. Werner, A.D.; Ward, J.D.; Morgan, L.K.; Simmons, C.T.; Robinson, N.I.; Teubner, M.D. Vulnerability indicators of sea water intrusion. Groundwater 2012, 50, 48-58. [CrossRef]

95. De Franco, R.; Biella, G.; Tosi, L.; Teatini, P.; Lozej, A.; Chiozzotto, B.; Giada, M.; Rizzetto, F.; Claude, C.; Mayer, A.; et al. Monitoring the saltwater intrusion by time lapse electrical resistivity tomography: The Chioggia test site (Venice Lagoon, Italy). J. Appl. Geophys. 2009, 69, 117-130. [CrossRef]

96. Kazakis, N.; Pavlou, A.; Vargemezis, G.; Voudouris, K.S.; Soulios, G.; Pliakas, F.; Tsokas, G. Seawater intrusion mapping using electrical resistivity tomography and hydrochemical data. An application in the coastal area of eastern Thermaikos Gulf, Greece. Sci. Total Environ. 2016, 543, 373-387. [CrossRef]

97. Pidlisecky, A.; Moran, T.; Hansen, B.; Knight, R. Electrical Resistivity Imaging of Seawater Intrusion into the Monterey Bay Aquifer System. Groundwater 2016, 54, 255-261. [CrossRef]

98. Haldorsen, S.; Heim, M.; Dale, B.; Landvik, J.Y.; van der Ploeg, M.; Leijnse, A.; Salvigsen, O.; Hagen, J.O.; Banks, D. Sensitivity to long-term climate change of subpermafrost groundwater systems in Svalbard. Quat. Res. 2010, 73, 393-402. [CrossRef]

99. Van der Ploeg, M.J.; Haldorsen, S.; Leijnse, A.; Heom, M. Subpermafrost groundwater systems: Dealing with virtual reality while having virtually no data. J. Hydrol. 2012, 475, 42-52. [CrossRef]

100. Tolstikhin, N.I. Groundwater of the permafrost region of the USSR. In Permafrost Second International Conference, 13-28 July 1973; Sanger, F.J., Hyde, P.J., Eds.; Yakutsk. U.S.R.R. USRR Contribution, National Academy of Sciences: Washington, DC, USA, 1973; pp. 724-733. 
101. Gregersen, O.; Phukan, A.; Johansen, T. Engineering properties and foundation design alternatives in marine Svea clay, Svalbard. In Proceedings of the 4th International Conference on Permafrost, Fairbanks, AK, USA, 17-22 July 1983; Norwegian Geotechnical Institute: Oslo, Norway, 1985; Volume 159, pp. 384-388.

102. Tsytovich, N.A.; Kronik, Y.A.; Markin, K.F.; Aksenov, V.I.; Samuel'son, M.V. Physical and mechanical properties of saline soils. In Permafrost Second International Conference, 13-28 July 1973; Sanger, F.J., Hyde, P.J., Eds.; Yakutsk, U.S.R.R. USRR Contribution, National Academy of Sciences: Washington, DC, USA, 1978; pp. 238-247.

103. MacKay, D.K. Electrical resistivity measurements in frozen ground, Mackenzie Delta area, Northwest Territories. In Association Internationale d'Hydrologie Scientifique, Actes du Colloque de Becarest; Reprint Ser. 82; Department of Energy, Mines and Resources, Inland Waters Branch: Ceuterick, Belgium, 1969; pp. 363-375.

104. Arcone, S.A.; Delaney, A.J. Borehole investigations of the electrical properties of frozen silt. In Permafrost, Proceedings of the Fifth International Conference, Trondheim, Norway, 2-5 August 1988; Senneset, K., Ed.; Proceedings Volume 2; Tapir Pub.: Trondheim, Norway, 1988; pp. 910-915.

105. Kearey, P.; Brooks, M.; Hill, I. Electrical surveying. In An Introduction to Geophysical Exploration, 3rd ed.; Blackwell Science Ltd.: New Jersey, NJ, USA, 2002.

106. Hilbich, C.; Marescot, L.; Hauck, C.; Loke, M.H.; Mäusbacher, R. Applicability of electrical resistivity tomography monitoring to coarse blocky and ice-rich permafrost landforms. Permafr. Periglac. Process. 2009, 20, 269-284. [CrossRef]

107. Lewkowicz, A.G.; Etzelmüller, B.; Smith, S.L. Characteristics of discontinuous permafrost based on ground temperature measurements and electrical resistivity tomography, Southern Yukon, Canada. Permafr. Periglac. Process. 2011, 22, 320-342. [CrossRef]

108. Kneisel, C. Frozen ground conditions in a subarctic mountain environment, Northern Sweden. Geomorphology 2010, 118, 80-92. [CrossRef]

109. Wu, Y.; Nakagawa, S.; Kneafsey, T.J.; Dafflon, B.; Hubbard, S. Electrical and seismic response of saline permafrost soil during freeze-Thaw transition. J. Appl. Geophys. 2017, 146, 16-26. [CrossRef]

110. Smith, M.W. Observations of soil freezing and frost heave at Inuvik, Northwest Territories, Canada. Can. J. Earth Sci. 1985, 22, 282-290. [CrossRef]

111. Strozzi, T.; Kääb, A.; Frauenfelder, R. Detecting and quantifying mountain permafrost creep from in situ inventory, space-borne radar interferometry and airborne digital photogrammetry. Int. J. Remote Sens. 2004, 25, 2919-2931. [CrossRef]

(C) 2020 by the authors. Licensee MDPI, Basel, Switzerland. This article is an open access article distributed under the terms and conditions of the Creative Commons Attribution (CC BY) license (http://creativecommons.org/licenses/by/4.0/). 